""This is the peer reviewed version of the following article: [Journal of Business Finance and Accounting, 2019], which has been published in final form at [https://onlinelibrary.wiley.com/doi/abs/10.1111/jbfa.12410]. This article may be used for noncommercial purposes in accordance with Wiley Terms and Conditions for Self-Archiving." 


\title{
Powerful CEOs, cash bonus contracts and firm performance
}

\author{
Rebecca L. Bachmann*, University of Technology Sydney \\ Rebecca.Bachmann@uts.edu.au \\ Anna Loyeung, University of Technology Sydney \\ Anna.Loyeung@uts.edu.au \\ Zoltan P. Matolcsy, University of Technology Sydney \\ Zoltan.Matolcsy@uts.edu.au \\ Helen Spiropoulos, University of Technology Sydney \\ Helen.Spiropoulos@uts.edu.au
}

\begin{abstract}
We investigate whether powerful chief executive officers (CEOs) influence the conditions of their cash bonus contracts. Specifically, we examine (i) the association between CEO power and the proportion of ex ante cash bonus to base salary (bonus ratio), (ii) the association between CEO power and the relative use of non-financial to financial targets in cash bonus contracts, and (iii) the performance consequences of incorporating non-financial targets in cash bonus contracts. Results show that powerful CEOs are associated with greater ex ante bonus ratios and higher proportions of non-financial performance targets compared to less powerful CEOs. Furthermore, the use of quantitative and CSR-related non-financial performance targets is positively associated with subsequent firm performance, and the use of undefined nonfinancial performance targets is associated with negative subsequent firm performance. These results are robust to alternative econometric specifications and variable definitions.
\end{abstract}


Keywords: CEO power, cash bonus, CEO compensation, incentive compensation, co-option, short-term incentives, non-financial performance targets, managerial power, efficient contracting, CSR.

JEL Classifications: J33, M12, M51, M52.

Data Availability Statement: The data that support the findings of this study are available from the corresponding author upon reasonable request and on the condition that this paper be referenced accordingly.

We gratefully acknowledge the valuable feedback from the editor Peter Clarkson and two anonymous reviewers, as well as the participants at the University of Technology Sydney Research Consortium and the British Accounting \& Finance Association annual conference 2018. Particularly, David Bond, Martin Bugeja, Andrew Ferguson, Samir Ghannam, Matthew Grosse, Le Ma, Nelson Ma, Nicole Sutton, Stephen Taylor, Jonathan Tyler and Jin Sug Yang. 


\section{Introduction}

There are two alternative theoretical explanations for CEO incentive compensation; efficient contracting theory (Jensen \& Meckling, 1976) and managerial power theory (Bebchuk \& Fried, 2003; 2005). While much of the earlier empirical evidence is consistent with efficient contracting theory (Conyon et al., 2011; Frydman \& Jenter, 2010; Murphy, 2013; Shan and Walter, 2016), there is an emerging body of literature that supports managerial power theory. This literature suggests that CEO attributes and power influence many aspects of corporate decision-making, including compensation arrangements (Abernethy, Kuang, \& Qin, 2015; Morse, Nabda, \& Seru, 2011; Song \& Wan 2019). To date, empirical studies have mainly focused on CEOs' equity-based pay (e.g., restricted stock grants and stock options). However, the influence of powerful CEOs on their cash bonus conditions remains unexplored, despite cash bonuses representing an ongoing and substantial part of CEOs' compensation package (Frydman \& Jenter, 2010; Conyon et al., 2011; Murphy, 2013; Shan \& Walter, 2016). ${ }^{1}$

Accordingly, we examine whether powerful CEOs influence the conditions of their cash bonus contracts and how these contracts impact on subsequent firm performance. Specifically, the objectives of this study are to provide empirical evidence on (i) the association between CEO power and the proportion of ex ante cash bonus to base salary (hereafter referred to as bonus ratio); (ii) the association between CEO power and the proportion of non-financial targets (such as product quality, strategic planning and leadership skills) to financial targets (such as firm sales and profits) in cash bonus contracts, and (iii) the performance implications of incorporating non-financial performance targets into CEOs' cash bonus contracts. Consistent with prior studies, CEO power is defined as the ability of the CEO to significantly influence firm directors and corporate decision-making, thereby revoking the effectiveness of corporate governance mechanisms (Bebchuk and Fried, 2003; 2005). 
The motivation for this study is twofold. First, executive compensation has received renewed scrutiny following the global financial crisis and the introduction of say-on-pay legislation (Alissa, 2015; Collins, Marquardt \& Niu, 2019; Clarkson, Walker, \& Nicholls, 2011; Correa \& Lel, 2016; Grosse, Kean, \& Scott, 2017; Iliev \& Vitanova, 2019). In response, many companies attempt to justify large compensation packages by offering performancebased pay in the form of equity grants and options. However, the performance targets used in these contracts may offer an avenue for firms to camouflage higher pay (e.g., Abernethy et al., 2015). While the literature is informative about the strategic use of stock and option grants, we argue that cash bonuses may be used as another means to camouflage high levels of executive pay. This is particularly relevant within the Australian setting where equity-based compensation is still emerging and cash bonuses are not subject to tax deduction limits. ${ }^{2}$ Specifically, cash bonuses can be as much as five times the CEO's base salary. Moreover, the comprehensive disclosure of compensation-related performance targets in firms' annual reports in Australia (Clarkson, Van Bueren, \& Walker, 2006), allows us to perform a detailed examination of the types of performance measures used in cash bonus contracts and their association with subsequent firm performance.

Second, while concerns have been raised about the use of non-financial measures in compensation contracts, empirical evidence is limited. In particular, practitioners and regulators have expressed growing discontent about the use of non-financial measures due to the prevalence of high bonus payments (Bennett, Bettis, Gopalan, \& Milbourn, 2017; Rose, 2017; Yeates, 2017). Specifically, the perceived fairness of CEOs' cash bonus contracts plays a major role surrounding the outrage about executive compensation (Arnold \& Grasser, 2018). Concerns are that non-financial measures may be easier to manipulate, hence reward CEOs for activities which should be considered part of their job description (Knight, 2016; Robertson, 2016). Knight (2016) reports in the financial press that: 
[...] some shareholders rallied against what they considered the easiness of meeting these [non-financial] hurdles which they believe is due to the fact they are not sufficiently focused on hard quantitative financial measures like total shareholder returns or returns on investment or even just statutory profit.

Furthermore, the fact that equity-based incentives have begun to incorporate non-financial performance targets highlights the importance of evaluating shareholders' concerns regarding the legitimacy of these measures (Ryan, 2017). As a result, we shed light on whether practitioners' concerns about the use of non-financial measures are justified by the type of nonfinancial measured used (i.e., qualitative, undefined, quantitative and CSR focused) and their impact on subsequent firm performance.

The empirical evidence provided in this study is based on a sample of 1,085 firm year observations from the Australian Stock Exchange (ASX) Top 500 listed firms for the period 2004 to 2016. The bonus ratio and the proportion of non-financial to financial targets are calculated based on hand-collected data. Following prior literature, which suggests that a single measure of CEO power fails to capture the overall level of CEO influence within the firm (Core, Holthausen, \& Larcker, 1999; Finkelstein, 1992), we construct a CEO power index consisting of eight measures. Our measure of CEO power contains characteristics which capture historical and new measures of power, including CEO tenure, shareholdings, board size, board independence, subcommittee membership, and co-option of directors on the remuneration committee (Abernethy et al., 2015; Core et al., 1999; Finkelstein, 1992; Lisic, Neal, Zhang, \& Zhang, 2016). ${ }^{3}$

Our findings support the contention that powerful CEOs influence the conditions of their cash bonus contracts. Specifically, CEO power is positively associated with the bonus ratio. This suggests that powerful CEOs justify their compensation by linking a greater proportion of their pay to performance-based bonus compensation as opposed to base salary. Moreover, we find a positive association between CEO power and the relative weight placed on non-financial performance targets, suggesting that non-financial measures may be used to 
compensate powerful CEOs for facets of their managerial effort. However, this finding may also signify that powerful CEOs incorporate non-financial measures to increase CEO compensation above what is justified by economic performance of the firm (Ittner, Larcker, \& Rajan, 1997).

To shed light on these alternative interpretations of our findings, we examine whether the use of non-financial targets in bonus contracts is associated with subsequent firm performance. If non-financial measures are used to encourage powerful CEOs to act in a manner that is consistent with shareholders' interests, we expect a positive association between the use of non-financial targets and subsequent firm performance. Alternatively, if nonfinancial measures are used by powerful CEOs to increase their compensation beyond a level justified by the firm's economic performance, we expect a negative association between the use of non-financial targets and subsequent firm performance. This is possible as non-financial targets are more prone to manipulation and are rarely subject to external verification (e.g., Ittner et al., 1997). We find that the use of non-financial measures which are quantitative, and consequently verifiable, is positively associated with industry-adjusted return on assets, as are performance targets linked to corporate social responsibility (CSR). These findings support the view that the use of objective performance targets (Ittner et al., 1997) and CSR performance targets (e.g., Cook, Romi, Sánchez \& Sánchez, 2019; Dhaliwal, Li, Tsang, \& Yang, 2011; Lev, Petrovits, \& Radhakrishnan, 2010) has positive firm performance implications. Interestingly, the use of performance targets that are not defined in annual reports (i.e., when a firm mentions using non-financial performance targets but does not provide any information as to what these targets are) is negatively related to subsequent firm performance. This is noteworthy as $44.54 \%$ of firms in our sample include targets that are not defined. These findings support the view that performance targets subject to a greater degree of discretion are a means of camouflaging executive compensation levels as such targets do not provide sufficient incentives to increase 
subsequent firm performance. To address endogeneity concerns, we perform a two-stage least squares and use a propensity score matched subsample. Although our empirical findings remain consistent, we cannot completely rule out that endogeneity is driving our results, which is a limitation of this study.

The findings of this study make important contributions to the literature and has implications for regulators. First, our findings add to the debate concerning whether efficient contracting theory or managerial power theory explains CEO compensation levels and structure (Abernethy et al., 2015; Balsam, Gifford \& Puthenpurackal, 2017; Bebchuk \& Fried, 2003; 2005; Lisic et al., 2016; Morse, Nanda, \& Seru, 2011; Murphy, 2013; Song \& Wan 2019). The prevalence of CEO cash bonuses at consistently high levels, and the common use of nonfinancial targets in determining cash bonuses, further highlight the importance of examining how performance conditions are designed and applied in CEOs' bonus contracts (Maley, 2018; Yeates, 2017). Our findings suggest that powerful CEOs receive large cash bonuses relative to their salary and that these cash bonuses are often based on non-financial targets. Interestingly, firms that do not disclose any information on the type of non-financial targets used in cash bonus contracts experience lower subsequent performance than firms that explicitly define their non-financial targets. These findings are of particular interest to practitioners and regulators who have expressed concerns that bonus compensation contracts are designed in a way that maximises CEO compensation and do not always lead to better firm performance.

Second, we contribute to the literature that examines the costs and benefits of subjective targets in executive compensation contracts (e.g., Bushman, Indjejikian, \& Smith, 1996; Gibbs, Merchant, Van der Stede, \& Vargus, 2004; Höppe \& Moers, 2011; Ittner \& Larcker, 1998; 2001; 2009; O’Connor, Deng, \& Fei, 2015; Rajan \& Reichelstein, 2009). While subjective performance measures are less verifiable (i.e., they are not audited), the literature has argued that such measures can be informative about various aspects of managerial actions not captured 
by objective performance measures (Bushman et al., 1996; Ittner \& Larcker, 1998; 2001; 2009). Additionally, subjective performance measures are used when there is noise in objective performance measures (Gibbs et al., 2004; Höppe \& Moers, 2011). Empirical evidence on whether the use of subjective targets in executive compensation is associated with firm performance is, however, rare. For example, using proprietary data on department managers' compensation contracts, Gibbs et al. (2004) do not find subjective bonuses to be associated with department productivity and profitability. We address this gap in the literature by documenting that the use of subjective (qualitative) non-financial measures is not associated with subsequent firm performance while objective (quantifiable) non-financial measures are positively associated with subsequent firm performance. We are able to do so by exploiting the Australian setting which provides a rich source of information about CEO bonus contracts (see Appendix A).

Third, our study contributes to the literature on CSR reporting and firm performance (e.g. Cook et al., 2019; Dhaliwal, Li, Tsang, \& Yang, 2011; Lev et al., 2010). Prior studies argue that CSR reporting provides information about firm performance beyond the information contained in accounting numbers such as earnings. For instance, customer satisfaction and spill-over effects of word of mouth advertising have been shown to be positively associated with firm performance (Gruca \& Rego, 2005; Ittner \& Larcker, 1998; O’Connell \& Sullivan, 2011; Tuli \& Bharadwaj, 2009). Additionally, socially responsible firms appeal to certain customers and have been found to be associated with superior sales and firm performance (Lev et al., 2010). Socially responsible firms can also attract and retain high quality employees, which contributes to firm value (Edmans, 2011; Mao \& Weathers, 2019). Furthermore, commitment to social and environmental activities can decrease lawsuits and environmental costs (Dhaliwal et al., 2011) and increase investment efficiency and innovation (Cook et al., 2019). Overall, while prior literature is informative in documenting an association between 
CSR and firm performance, little is known about the role CSR measures play in compensation contracts (O’Connell \& Sullivan, 2011). Some studies examine the association between types of CEO compensation and CSR performance (e.g., Cai, Jo, \& Pan, 2012; Mahoney \& Thorne 2005; 2006), while others examine predictors of the use of CSR measures in compensation contracts (e.g., Hong, Li, \& Minor, 2016). They do not, however, link CSR performance measures in compensation contracts to subsequent firm financial performance. We address this gap in the literature by documenting that aligning CEO incentives to CSR performance (based on customer satisfaction, staff safety and satisfaction, internal governance standards and sustainability) has positive firm performance. Specifically, our study highlights that linking performance-based incentive pay to CSR performance is positively associated with subsequent industry-adjusted ROA.

The remainder of this study is structured as follows: Section 2 reviews the relevant literature and develops the hypotheses to be tested. Section 3 presents the research design. Section 4 describes the sample selection process and Section 5 reports the empirical results. Section 6 presents additional analyses and Section 7 concludes.

\section{Relevant literature and hypotheses development}

\subsection{Relevant literature}

Numerous authors have provided an overview of the agency and managerial power explanations of CEO compensation and the accompanying empirical evidence (e.g., Frydman \& Jenter, 2010; Murphy, 2013; Shan \& Walter, 2016). Overall, they document that firms, on average, efficiently address the agency problem between managers and shareholders. ${ }^{4}$ Nonetheless, some inconsistencies remain. Specifically, recent evidence suggests that powerful CEOs are able to influence their compensation arrangements (Abernethy et al., 2015; Morse et al., 2011). For example, using U.S. data for the period 1992 to 2003, Morse et al. (2011) find 
that powerful CEOs are able to extract rents and increase their total compensation by opportunistically altering the focus of their incentive pay towards better performing measures. Similarly, Abernethy et al. (2015) examine the association between equity-based incentives and CEO power for the period 1997 to 2004. They show that powerful CEOs are able to influence the adoption and choice of performance targets implemented in performance-vested stock option plans, particularly in an attempt to appease public outrage. Similar results have been found with regard to CEO bonuses within the UK setting (Cho, Ibrahim and Yan 2019). Overall, these studies suggest that both the mix of performance targets as well as individual targets are influenced by powerful CEOs.

More recently, it has been argued that discrepancies exist between the empirical evidence on cash bonuses and practices in the industry (Guay, Kepler, \& Tsui, 2019). The literature on CEO incentive contracts concludes that incentives from cash bonuses are modest compared to equity-based compensation. However, the vast majority of U.S. executive compensation plans incorporate cash bonus payouts, which may offer CEOs liquidity (Guay et al., 2019). Furthermore, the pay-for-performance sensitivity of CEO cash compensation is much greater than estimated in prior studies (Guay et al., 2019). We extend the existing literature by focusing on cash bonuses, which is particularly relevant today given that a recent CEO pay survey and corresponding media coverage have raised questions about whether such bonuses adequately reflect firm performance (e.g., Rose, 2017; Yeates, 2017).

\subsection{Hypotheses development}

The ASX Corporate Governance Council (2014, p. 33) recommends firms remunerate fairly and responsibly through 'an appropriate balance of fixed remuneration and performancebased remuneration'. This approach aims to align the interests of CEOs to that of shareholders as excessive base salaries can negatively impact subsequent firm performance by increasing 
CEOs' risk aversion (Gerhart \& Milkovich, 1990). Specifically, CEOs who only receive base salaries have incentives to accept (reject) projects that reduce (increase) the volatility of the firm's cash flow, regardless of their net present value (Guay, 1999; Smith \& Watts, 1982). Therefore, instead of being remunerated with large salaries which may encourage investor outrage, CEOs may camouflage high compensation levels in the form of incentive compensation (such as cash bonuses) which are justified by meeting set performance targets.

Given the above, we argue that powerful CEOs negotiate a greater cash bonus relative to base salary to camouflage higher compensation levels; base salaries are generally fixed over time and no guidelines exist on what should be considered an appropriate bonus ratio. Furthermore, cash bonuses are less likely to come under public scrutiny because, unlike base salaries, they are justified by various measures of performance. This leads to the following hypothesis:

\section{H1: There is a positive association between bonus ratio and CEO power.}

In addition to recommending that executive remuneration incorporates a balance of fixed and incentive compensation, the ASX Corporate Governance Council (2014, p. 33) suggests that 'performance-based compensation is linked to clearly specified performance targets [...] aligned to the entity's short and long-term performance objectives' in order to appropriately reflect the various responsibilities of executives. Nonetheless, whether these performance targets are associated with financial or non-financial targets is within the firms' discretion.

Non-financial performance targets, such as having a focus on innovation, are a crucial part of effective incentive compensation arrangements (Guay et al., 2019). However, as nonfinancial performance targets are specific to the individual firm, these measures may be more 
subjective than performance associated with quantitative financial targets. Furthermore, nonfinancial targets change more frequently and do not always display the same stable year-onyear patterns as financial targets (Ittner et al., 1997). These characteristics raise the concern of investors and market analysts as they make manipulation possible, while at the same time making sanctions from outside auditors difficult, particularly as non-financial targets cannot easily be compared to industry benchmarks (Ittner et al., 1997; Robertson, 2016). Consequently, powerful CEOs may be able to apply their influence to negotiate a greater proportion of non-financial performance targets to be included in their cash bonus contract in order to achieve the greatest payoff possible. We predict that, in order to minimise compensation risk, powerful CEOs influence target choices and set easier targets ex ante or targets that can be manipulated ex post (i.e., non-financial performance targets) (Abernethy et al., 2015; Morse et al., 2011). This leads to the following hypothesis:

H2: There is a positive association between CEO power and the proportion of nonfinancial targets used in cash bonus contracts.

Thus far, this study has focused on the notion that powerful CEOs are able to obtain their preferred bonus conditions by exercising influence over corporate governance mechanisms. However, whether CEOs' preferred bonus conditions have any implications for firm performance is yet to be determined. Efficient contracting theory suggests that executive compensation contracts reflect a firm's economic characteristics and provide managers with incentives to maximise shareholder value (Core et al., 1999; Holmstrom, 1979; Matolcsy \& Wright, 2011). If firms contract efficiently, we expect a positive association between incentive compensation and subsequent firm performance (O'Connell \& Sullivan, 2014). Alternatively, managerial power theory suggests that incentive contracts are a manifestation of CEO power 
and enable rent extraction resulting in negative subsequent firm performance (Bebchuk \& Fried, 2003, 2005; Bugeja, Matolcsy, \& Spiropoulos, 2017). Early studies fail to explore in detail how such compensation contracts result in negative firm performance. However, recent studies find that targets which are more easily achieved negatively impact subsequent firm performance (Abernethy et al., 2015; Morse et al., 2011;). Unlike financial targets, nonfinancial targets are less objective and easier to manipulate ex post. ${ }^{5}$ This leads to the following hypothesis:

H3a: There is a negative association between the proportion of non-financial targets used in cash bonus contracts and subsequent firm performance.

Prior studies provide various theories as to why firms use non-financial targets in compensation contracts. In particular, non-financial targets are used to capture multiple dimensions of a CEO's actions and when financial measures are noisy (Bushman et al., 1996; Gibbs et al., 2004; Höppe \& Moers, 2011; Ittner \& Larcker, 1998; 2001; 2009; O’Connor et al., 2015; Rajan \& Reichelstein, 2009). To further understand the types of non-financial measures used in bonus contracts and whether they impact subsequent firm performance, we decompose non-financial targets into those that are: quantifiable, qualitative, undefined, and those that measure aspects of CSR. We predict that non-financial targets that are qualitative in nature or undefined are used as a camouflage, hence are negatively associated with firm performance (Abernethy et al., 2015). These types of non-financial targets are problematic because they are subject to issues such as reneging, favouritism and bias (Höppe \& Moers, 2011). Moreover, they are easier for powerful CEOs to defend. In contrast, non-financial targets that are quantifiable and less manipulable by powerful CEOs are expected to be positively associated with subsequent performance. 
Finally, prior studies document that focusing on the wellbeing of customers, employees and the environment has a positive impact on firm performance (e.g., Cook et al., 2019; Edmans, 2011; Ittner \& Lacker, 1998; Lev et al., 2010). Specifically, we predict that incorporating non-financial targets centred around CSR in CEOs' bonus contracts encourages CEOs to focus on these important issues, ultimately positively impacting future firm performance. This leads to the following hypotheses on the specific types of non-financial targets used in CEOs' cash bonus contracts:

H3b: There is a negative association between non-financial targets that are qualitative or undefined and subsequent firm performance.

H3c: There is a positive association between the proportion of non-financial targets that are quantitative and subsequent firm performance.

H3d: There is a positive association between the proportion of non-financial targets which focus on CSR and subsequent firm performance.

\section{Research design and variable measurement}

The following ordinary least squares (OLS) regression model is estimated to test hypotheses $H 1$ and $H 2{ }^{6}$

$$
\begin{aligned}
\text { Dependent Variable }= & \alpha+\beta_{1} \text { CEO Power Index }+\beta_{2-12} \text { S Firm Controls } \text { Co }_{t-1} \\
& +\beta_{13-25} \text { Year }+\beta_{26-35} \text { Industry }+\epsilon_{i}
\end{aligned}
$$


The alternate dependent variables applied in Model (1) are Bonus Ratio and Non_Fin. Ratio. Bonus Ratio is the maximum ex ante cash bonus available to the $\mathrm{CEO}$ as a proportion of their base salary as stated in the firm's remuneration report. Non_Fin. Ratio is the proportion of cash bonus weighted towards non-financial performance targets. CEO Power Index and firm control variables are described in Sections 3.1 and 3.2 and defined in Table 1.

Model (2) tests the association between subsequent firm performance and the use of non-financial performance targets in cash bonus contracts $(H 3)$. The dependent variable is an industry-adjusted return on assets $\left(R O A_{t+1}\right)$, calculated by subtracting the industry mean ROA for firm $i$ in year $t+1$.

$$
\begin{array}{r}
R O A_{t+1}=\alpha+\beta_{1} \text { Non_Fin. Ratio }+\beta_{2-5} \text { SFirm Controls } \text { Ci-1 }_{t-1} \\
+\beta_{5-18} \text { Year }+\beta_{19-28} \text { Industry }+\epsilon_{i}
\end{array}
$$

To test $H 3 b$ through $H 3 d$, the independent variable Non_Fin. Ratio is replaced with a variable that captures qualitative, undefined, quantitative, and CSR non-financial performance measures, respectively. Furthermore, because the use of equity-based compensation is still emerging within the Australian setting, we estimate both models first on the full sample and then on subsamples of cash-only and equity-based compensation firms.

\subsection{Key independent variables}

\subsubsection{CEO power index}

Consistent with Bebchuk and Fried (2003; 2005), managerial power is defined as the ability of the CEO to influence firm directors and corporate decision-making. Following this notion, a number of researchers have examined CEO power in various corporate decisions. ${ }^{7}$ Comprehensively, these authors recognise that any single measure of power may not be able to capture the overall level of CEO influence. Accordingly, we measure CEO power as a 
summary index based on eight CEO characteristics capturing three dimensions of CEO power identified by Finkelstein (1992). ${ }^{8}$

\section{[Insert Table 1 here]}

Following prior literature, we create a unidimensional measure of CEO power (Lisic et al., 2016). First, we measure the number of years the CEO has been employed as CEO of the firm because their ability to influence board decisions is likely to increase with tenure (Abernethy et al., 2015; Bebchuk and Fried 2003;2005; Core et al., 1999; van Essen, Otten, \& Carberry, 2015). Second, we assess the CEOs' shareholdings relative to total outstanding shares. CEOs with greater shareholding are likely to be more powerful as they have greater voting power, increased ownership control, and consequently are more likely to be entrenchmed in the board (Core et al., 1999). Third, we consider board size since the board's efficiency in constraining CEO power and generating cohesive decisions is lower when the number of directors is large (Abernethy et al., 2015; Matolcsy, Tyler, \& Wells, 2011). Fourth, we account for the relative proportion of independent directors on the board as they are less likely to be vulnerable to conflicts of interest with corporate insiders and consequently diminish CEO power (Abernethy et al., 2015; Bebchuk \& Fried, 2003; 2005). Fifth, we assess the extent to which the CEO is involved and can influence various corporate decisions by considering the number of board subcommittees on which the CEO sits. Board subcommittees create a concentration of decision-making rights and increase the ability of CEOs to influence these committees during the decision-making process (Abernethy et al., 2015; Core et al., 1999;). Specifically, we consider how many committees the CEO sits on, as well as whether the CEO is a member of the nomination and/or remuneration committee. The nomination committee is intended to make independent decisions regarding the composition of the board of directors (ASX Corporate Governance Council, 2014). Similarly, CEOs who are on the remuneration committee should not be involved in deciding their own remuneration arrangements. Despite 
such recommendations, Conyon and Peck (1998) find that CEOs who are on the remuneration committee obtain higher compensation packages than CEOs who are not. Last, powerful CEOs may impair the function of the remuneration committee by appointing directors who are independent but beholden to their agenda (i.e., they are co-opted). Co-option is a commonly cited concern in the corporate governance literature and evidence suggests that independent directors who are co-opted by the CEO are associated with weaker monitoring efficiency (Coles, Daniel, \& Naveen, 2014). Similarly, co-opted directors have been found to be associated with higher total CEO compensation (Core et al., 1999). Therefore, we predict that co-opted remuneration committees enable CEOs to influence the conditions of their compensation contracts. ${ }^{9}$

Comprehensively, the CEO power score ranges from 0 to 8 . In order to account for the fact that some firms do not have a nomination committee and/or remuneration committee, the CEO power score is subsequently divided by the maximum power available to a CEO. This creates the CEO Power Index applied in Model (1).

\subsubsection{Non-financial targets}

Recently, there has been an increased emphasis on the use of non-financial performance targets such as customer satisfaction, innovation and market share in cash bonus contracts (Yeates, 2017). The increasing use of non-financial performance targets has raised concerns among analysts and shareholders that such targets can be manipulated easily and reward CEOs for activities that should be a normal part of their job description (Knight, 2016; Robertson, 2016). In order to examine the consequences of negotiated cash bonus contracts on subsequent firm performance, we capture the relative weights placed on financial and non-financial performance targets in CEOs' cash bonus contracts. An underlying assumption when applying these measures is that bonus contracts and their conditions are established at the beginning of the financial year (Shaw \& Zhang, 2010). ${ }^{10}$ 
To test $H 3 a-H 3 d$ we decompose non-financial targets into those that are: qualitative (Qualitative), undefined (Undefined), quantitative (Quantitative), and include measures of CSR (CSR). These decomposed measures are used alternatively in model (2) in order to examine how each of these types of non-financial targets impacts subsequent firm performance. Appendix A outlines all the categories of non-financial targets identified during the data collection process. These are used to construct the variables Qualitative, Undefined, Quantitative, and CSR as detailed in Table 1.

\subsection{Control variables}

Based on prior literature, we include as controls economic characteristics that are expected to determine a firm's relative demand for a particular type of compensation contract (e.g., Core et al., 1999; Matolcsy \& Wright, 2011). These include: return-on-assets $\left(R O A_{t-1}\right)$; the natural $\log$ of total assets $\left(\operatorname{lnSize}_{t-1}\right)$ as a proxy for firm size; the standard deviation of return on assets $\left(s_{d} R O A_{t-1}\right)$ to proxy for risk; the natural log of operating cash flow scaled by total assets $\left(\operatorname{lnCash}_{t-1}\right)$; annual stock return (Return $\left.{ }_{t-1}\right)$; the debt to equity ratio (Leverage $\left.{ }_{t-1}\right)$ to capture external monitoring by large debtholders; growth measured as the market-to-book ratio $\left(M / B_{t-}\right.$ 1); and year and industry fixed effects. ${ }^{11}$

We include an indicator variable equal to 1 if the firm employs a compensation consultant during the year (Consultant); the literature suggests that compensation consultants have economic incentives to bias their recommendations upwards to please management (Bebchuk \& Fried, 2003; 2005; Grosse et al., 2019; Murphy \& Sandino, 2019). Specifically, increases in compensation, equity and cash bonuses in particular, are associated with firms that employ a compensation consultant. (Grosse et al., 2019). Last, we control for any change in base salary ( $\triangle$ Salary) to capture the impact on the bonus ratio should base salary change significantly compared to the prior year. 


\section{Sample and data}

\subsection{Sample selection}

Data on CEO compensation and board characteristics are obtained from the Connect 4 database and firm characteristics data are obtained from the DatAnalysis database for the period from 2004 to 2016. Information on the use of remuneration consultants is hand collected. Similarly, data to construct the Bonus Ratio and Non_Fin. Ratio, as well as the decomposed measures, are hand collected from the remuneration reports provided in firms' annual reports.

The sample used in this study comprises the ASX Top 500 firms for the period 2004 to 2016. We focus on ASX Top 500 firms as these firms are more likely to disclose incentive targets used in CEO cash bonus contracts. We remove firm-year observations in which specific details about the cash bonus contract are not disclosed $(1,436)$, those which do not have a bonus scheme in place (154), firms in which the CEO receives payment from another firm (5), firms with co-CEOs (26), and firms in which there is a CEO change during the year (54). We also removed firms lacking data required for the empirical models (398). The final sample results in 1,085 firm-year observations to test $H 1$ and 687 firm-year observations to test $H 2$ and $H 3 a-$ $d{ }^{12}$ A breakdown of the sample selection is provided in Panel A of Table 2.

\section{[Insert Table 2 here]}

Panel B of Table 2 reports the annual distribution of firms by financial year. Although the frequencies of observations increase towards the later sample years, the sample is not dominated by any one year. The increase in frequencies over time may be caused by an improvement in reporting practices following the introduction of new reporting requirements in 2003 (Clarkson et al., 2011). The lowest frequency of observations occurs in 2004 (1.84 percent) whereas the highest occurs in 2016 (14.38 percent). Panel $\mathrm{C}$ of Table 2 provides the industry distribution based on 2-digit GICS and highlights that no one industry dominates the sample. The materials industry comprises the greatest proportion of firms within the sample 
(19.91 percent) followed by consumer discretionary (17.42 percent). Telecommunication services comprise the lowest number of firms within the sample $(0.74$ percent). This distribution is representative of the Australian setting and consistent with Matolcsy and Wright (2007).

\subsection{Descriptive statistics}

Table 3 reports the descriptive statistics for the total sample. All continuous variables are winsorized at the top and bottom five percent in order to reduce the effect of outliers. ${ }^{13}$

\section{[Insert Table 3 here]}

Of the dependent variables, the mean Bonus Ratio is 0.939, implying that CEOs in this sample are able to arrange an average bonus of $93.9 \%$ of their base salary, with a maximum of 511\%. The mean Non_Fin. Ratio is 0.371 , suggesting on average CEOs have $37.1 \%$ of their potential ex post cash bonus payout attributed to non-financial performance targets. The nonfinancial ratio ranges from zero to $100 \%$. Last, industry-adjusted ROA ( $R O A_{t+1}($ Ind-adj $\left.)\right)$ has a mean of $0.04 \%$ with a maximum of $17.6 \%$.

The key independent variables include the CEO Power Index and a breakdown of nonfinancial performance targets into different categories. The mean CEO Power Index is 0.319. This value is higher than that documented in prior research (e.g., Abernethy et al., 2015), but incorporates other facets of CEO power, such as membership of the remuneration or nomination committees. Of the types of non-financial performance targets, $64.9 \%(41.3 \%)$ of firms incorporate qualitative (quantitative) targets, $44.5 \%$ do not highlight the non-financial targets that are being used (Undefined), and 33\% use some form of corporate social responsibility $(C S R)$ targets.

Next, we report the descriptive statistics on the individual components of CEO power. The average CEO Tenure is 5.465 years, which is consistent with prior literature (e.g., Abernethy et al., 2015; Lisic et al., 2016). The mean CEO Shareholdings are $2.5 \%$ of total 
outstanding shares. The average Board Size of 6.590 is consistent with prior literature; $65.9 \%$ of the board consists of independent directors (\%Independent). On average, the CEO is a member on one in five of the board's subcommittees (CEO_Com of 19.5\%), with a maximum of $100 \%$. Of the firms in the sample, $15.7 \%(11.9 \%)$ of CEOs are a member of the nomination (remuneration) committee, and just over half of the CEOs in our sample have co-opted the remuneration committee (Coopted_Rem of 51.3\%). The number of observations reported for On_Nom,On_Rem and Coopted_Rem are lower due to the fact that not all firms in the sample have nomination or remuneration committees. Last, the control variables are consistent with those in prior literature (Matolcsy \& Wright, 2007; 2011).

\section{[Insert Table 4 here]}

Table 4 displays the correlation matrix for all variables. As expected, as the CEO Power Index is constructed based on the eight individual measures of $\mathrm{CEO}$ power (CEO Tenure, CEO Shareholdings, Board Size, \%Independent, CEO_Com, On_Nom, On_Rem and Coopted_Rem), significant correlations can be observed between these variables and CEO Power Index. The highest correlation is observed between On_Rem and CEO Power Index $(0.583, \mathrm{p}<0.01)$. Furthermore, as the likelihood of a board member being co-opted increases with the CEO's tenure, it can be expected that CEO Tenure and the measure of co-option (Coopted_50), are positively correlated $(0.491, \mathrm{p}<0.01)$. A negative correlation can be observed between \%Independent and CEO Power Index. This is consistent with prior literature and suggests that a greater proportion of independent directors limits the ability of CEOs to influence the board of directors (Abernethy et al., 2015; Lisic et al., 2016; Morse et al., 2011).

The correlation between CEO Power Index and Bonus Ratio is positive and significant (0.046, $\mathrm{p}<0.10)$, and consistent with H1. Moreover, the correlation between CEO Power Index and the Non_Fin. Ratio is also in the predicted direction and significant $(0.062, \mathrm{p}<0.10)$, consistent with H2. Industry adjusted ROA is not correlated with Non_Fin. Ratio but is 
positively correlated with Non_Fin. Ratio that includes measures of $C S R(0.116, \mathrm{p}<0.05)$. To ensure that multicollinearity is not a concern, VIF tests are conducted when running OLS regressions.

\subsection{Univariate analysis}

Table 5 presents a univariate analysis of the sample split at the $50^{\text {th }}$ percentile $(0.286)$ of the CEO Power Index. The top and bottom percentiles are classified as having high and low CEO power, respectively.

\section{[Insert Table 5 here]}

Bonus Ratio, Non_Fin. Ratio and industry-adjusted ROA are all significantly lower for the low power sub-sample in comparison to the high power sub-sample. This provides initial support for $\mathrm{Hl}$ and $\mathrm{H} 2$, that powerful CEOs are able to increase their cash bonus ratio and have greater levels of non-financial targets than less powerful CEOs. As expected, the CEO Power Index and its individual components differ significantly between the two subsamples. This suggests that the selected measures are appropriate representations of CEO power. Of the control variables, all firm characteristics, with the exception of Leverage and $\Delta$ Salary, do not differ significantly between the two subsamples. Consequently, it is unlikely that powerful CEOs self-select and choose firms with specific economic characteristics. Nevertheless, we conduct additional tests, reported in Section 6, to address this concern.

\section{Main results}

\subsection{CEO power and the bonus ratio}

Table 6 reports the results of estimating model (1) with Bonus Ratio as the dependent variable. We estimate model (1) on the full sample and then on subsamples of firms that offer cash-only compensation (column (2)) and those that also use equity-based pay (column (3)).

\section{[Insert Table 6 here]}


In column (1), the CEO Power Index coefficient is positive and significant $(0.288, \mathrm{p}<0.01)$, which increases in magnitude for the cash-only subsample $(0.543, \mathrm{p}<0.01)$ in column $(2)$, and reduces for the equity subsample $(0.167, \mathrm{p}<0.01)$ in column $(3)$. These results support $H 1$ in that there is a positive association between CEO power and the Bonus Ratio. The greater association between CEO power and bonus ratio for the cash-only subsample is expected given that there is no equity component of compensation for these CEOs to manipulate, hence the cash bonus is the only way of obtaining higher compensation and is easier to justify to shareholders than an increase in salary. This notion is also supported by the reduction in the size of the coefficient for the equity-pay subsample. Since the equity component of CEO compensation is generally much larger than the cash bonus and easier to camouflage, CEOs that receive equity-based incentives are more likely to attempt to influence the equity component of their compensation than those who do not. ${ }^{14}$

Of the control variables, the bonus ratio significantly increases with firm size (lnSize $\left._{t-1}\right)$ across all columns. However, in contrast to studies that find firms using a remuneration consultant pay their CEOs a greater proportion of total compensation as incentive payments (Grosse et al., 2019), this study finds that Consultant is inversely associated with the bonus ratio for the cash-only subsample but positively associated with bonus ratio for the equity subsample. This may be driven by the sample period, which extends before the Australian Treasury's Corporations Amendment (Improving Accountability on Director and Executive Remuneration) Bill 2011, which from 2011 onwards requires companies to disclose details of remuneration consultants used. Last, the amount of cash holdings (lnCash) is positively associated with the bonus ratio for the equity subsample.

\subsection{CEO power and the use of non-financial performance targets}

Table 7 reports the results of estimating model (1) with Non_Fin. Ratio as the dependent variable. 


\section{[Insert Table 7 here]}

The CEO Power Index is positive and significant across all columns with the largest effect being on the cash-only subsample reported in column (2) $(0.292, \mathrm{p}<0.05)$. These results support $H 2$, suggesting that powerful CEOs are able to negotiate a greater proportion of their cash bonus towards non-financial performance targets. The effect is lower for the equity subsample reported in column $(3)(0.090, \mathrm{p}<0.05)$ since it is likely that powerful CEOs would prefer to manipulate equity incentives that have a greater payout than cash bonus incentives. These findings are consistent with Abernethy et al. (2015) and Morse et al. (2011) who suggest that powerful CEOs are able to influence the conditions of their compensation arrangements. ${ }^{15}$

The control variables report significant coefficients, which overall support the notion that powerful CEOs place greater weight on more attainable performance indicators (Morse et al., 2011). For example, the negative and significant coefficient on $R O A_{t-l}$ across all columns suggests that when financial performance is easily attainable, bonus targets are more likely to

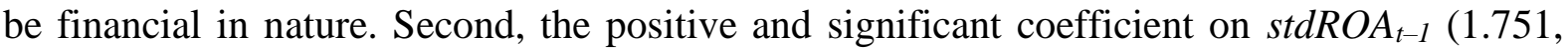
$\mathrm{p}<0.01$ ), which proxies for risk, suggests that the use of non-financial targets increases when financial performance measures are more volatile.

\subsection{The use of non-financial performance targets and subsequent firm performance}

Table 8 reports the results from estimating model (2), which examines the association between incorporating non-financial performance targets in cash bonus contracts and subsequent firm performance (measured as industry-adjusted ROA). We divide non-financial targets into specific categories, being Qualitative, Undefined, Quantitative, and CSR, and report the results of these dependent variables in columns (1) through (15) respectively.

\section{[Insert Table 8 here]}

We find no association between the ratio of non-financial performance targets and firm performance in general, and are therefore rejecting $H 3 a$. When examining the types of non- 
financial targets used in cash bonus contracts, we also do not observe any relation between Qualitative targets used and firm performance. However, when firms disclose that they use non-financial targets in cash bonus contracts but do not define or describe what those targets are (Undefined), there is a negative and significant relation with subsequent firm performance across all subsamples. Therefore, we find partial support for $H 3 b$. This result is consistent with the excess compensation literature which suggests that CEOs attempt to camouflage rent extraction from shareholders and that such rent extraction is associated with negative performance consequences (Bugeja et al., 2017; Core et al., 1999). When non-financial targets are quantitative in nature (Quantitative), we find a positive and significant relation across all subsamples, supporting $H 3 c$. Finally, when non-financial targets relate to $C S R$, there is also a positive and significant relation to subsequent firm performance for all subsamples, supporting $H 3 d$. This result adds to the existing literature on CSR and firm performance (e.g., Edmans 2011; Ittner \& Larcker, 1998; Lev et al, 2010) by documenting one channel through which higher firm performance is achieved, i.e., through the inclusion of CSR in performance-based pay. The control variables are largely consistent with prior literature.

\section{Additional analysis and robustness checks}

\subsection{Controlling for endogeneity}

A possible concern with the results is that powerful CEOs self-select to firms with specific economic characteristics, which in turn affects their compensation arrangements. We attempt to address this concern in four ways. First, the univariate analysis between high and low CEO power subsamples in Table 5 shows no real difference in the economic characteristics of firms

with high and low power CEOs. Second, an untabulated Hausman test fails to reject the null hypothesis, which states that the selected estimator is an efficient and consistent estimator of the true sample parameters to detect endogenous regressors. Nevertheless, we perform a two- 
stage Heckman estimation to evaluate the parameters of the regression model which may suffer from endogenous sample selection. The first-stage models the likelihood of a firm having a powerful CEO (columns (1) and (3)) using an indicator variable equal to 1 if the firm is audited by a big four audit firm (Big4) as an exogenous determinant of CEO power within a firm, 0 otherwise. External auditors play an important monitoring role on behalf of shareholders and are essential in companies' corporate governance (Cohen, Krishnamoorthy, and Wright, 2002; Francis et al., 2003; Sloan, 2001). However, their value ultimately depends on the quality of the audit provided. We focus on Big4 auditors due to the overwhelming evidence that they provide higher quality monitoring (DeAngelo 1981, Krishnan 2003; Francis and Yu 2009). Following Cohen et al. (2002) we argue that Big4 directly impacts on firms' corporate governance and operations (Cohen et al. 2002). We therefore use Big4 as a proxy for better corporate governance, which mitigates the ability of CEOs to establish power within the firm. We find that Big4 is negatively associated with CEO Power and contributes to $30 \%$ of the explanatory power (untabulated results). However, Big4 is not associated with the Bonus Ratio or Non.Fin_Ratio. Thus, we deem Big4 to be a suitable instrumental variable.

\section{[Insert Table 9 here]}

The dependent variable in the first-stage (Power_50) is an indicator variable equal to 1 if the CEO Power Index is above the median, and 0 otherwise. The second stage (columns (2) and (4)) report the results of model (1) after including the inverse Mills ratio. The coefficient on Big4 is negative and significant in columns (1) and (3), suggesting that there is monitoring by audit firms which restricts the level of power that CEOs are able to attain in these firms. In columns (2) and (4), the coefficients on Power_50 are positive and significant for Bonus Ratio and Non_Fin. Ratio, which is consistent with our previous findings.

Last, we attempt to control for endogeneity by using a propensity score matched (PSM) subsample. We estimate the probability of having a powerful CEO based on all covariates in 
model (1), then match firms with similar scores from the high and low CEO power subsamples. ${ }^{16}$ These results (untabulated) are consistent with our main results reported in Tables 6 and 7, which reduce our concern of endogeneity and reinforce our main findings that powerful CEOs influence the conditions of their cash bonus contracts.

\subsection{Alternate specifications}

A number of additional tests are conducted to confirm the robustness of the results (untabulated). First, the eight individual components of $C E O$ power have been included as key independent variables on their own. Overall, the results support the notion that any single measure of power may not be able to capture the overall level of CEO influence (Abernethy et al., 2015; Finkelstein, 1992; Lisic et al., 2016; Morse et al., 2011).

Second, the continuous measure of CEO power (CEO Power Index) has been measured using an indicator variable coded 1 if the CEO Power Index is in the $50^{\text {th }}$ percentile of the sample, and 0 otherwise (Power_50). Results are robust and consistent with results initially presented in Table 6 and Table 7. Third, instead of applying the proportion of non-financial performance targets (Non_Fin. Ratio) as the dependent variable, we use the proportion of financial performance targets as the dependent variable (Fin. Ratio). Consistent with initial findings, the coefficient on CEO power (CEO Power Index) is negative and significant.

Fourth, we use alternative measures of firm performance, including return on equity $\left(R O E_{(t+1)}\right)$ and buy and hold returns $\left(B H A R_{(t+1)}\right)$. Consistent with the main findings, we find that non-financial targets that are unclassified are negatively associated with $R O E_{(t+1)}$, while non-financial targets that are quantitative and focus on CSR performance are positively associated with $R O E_{(t+1)}$. The same findings do not hold consistently in the cash only and equity only sub-sample. Moreover, we do not find that non-financial measures are associated with $B H A R_{(t+1)}$. Overall, these findings support the view that cash bonus compensation is less likely to come under public scrutiny as they are justified by various measures of performance and 
shareholders do not seem to differentiate between the types of non-financial targets used. To further support this claim, we hand-collected data on say-on-pay votes the CEO's compensation. Although such votes enable shareholders to have a substantial role in aligning shareholder and executive interests (Collins et al., 2019), we only find 15 instances $(2.18 \%)$ where shareholders penalised CEOs who have non-financial measures in their bonus contracts, by voting against their compensation (first strike). None received a second strike. This is substantially lower than reported in prior literature which examines the association between equity-based incentives and shareholder say-on-pay outcomes, which may suggest that shareholders are apathetic or uninformed in their monitoring role in regards to cash bonuses (e.g. Collins et al., 2019). This finding further supports the contention that cash bonuses can provide an avenue for CEOs to camouflage their compensation.

\subsection{Long-term versus short-term non-financial targets}

Finally, we examine whether non-financial targets which have a long-term focus versus those with a short-term focus have implications for subsequent firm performance. ${ }^{17}$ The classification of non-financial measures into long-term and short-term is problematic since most of the non-financial targets may have both short- and long-term implications. For example, the CEO decreased the number of injuries this year by implementing a number of safety procedures. These safety procedures extend to the following years, hence injuries in subsequent years will also be lower. Further, developing strategic initiatives in the short-term, also has long-term consequences when these initiatives are implemented. Nevertheless, we try to address the long-term implications of non-financial targets by creating an indicator variable Long-term strategy, which is equal to 1 only if the firm explicitly states that the non-financial target is 'long-term', and 0 otherwise. We do not find a positive and significant coefficient on 
Long-term strategy. This result could be due to the fact that only $2.91 \%$ of firms have Longterm strategy in our sample.

\subsection{Ex post bonus payouts}

To triangulate our results, we further examine the association between CEO power, nonfinancial performance targets and the realised (ex post) bonus payout. We find that CEOs with high power are associated with greater ex post cash bonus payouts. Untabulated results suggest that powerful CEOs achieve greater bonus payouts through the use of discretionary, nonfinancial targets. Specifically, we find that CEOs who are compensated with a majority of nonfinancial targets achieve a greater proportion of their bonus contract (60 percent) compared to CEOs with a majority of financial targets (50 percent). ${ }^{18}$ Furthermore, CEOs on average achieve 10 percent more of their bonus contract if these non-financial targets are undefined (49.5 percent compared to 58.6 percent). In contrast, performance targets which are quantitative and are less likely to allow for manipulation by powerful CEOs result in lower cash bonus achievements (48.9 percent) compared to qualitative targets (57.1 percent). Anecdotal evidence supports this contention. In 2016, Insurance Australia Group CEO, Peter Harmer achieved approximately 70 percent of his bonus for the year as he, among other factors, demonstrated the 'IAG Spirit'. This resulted in a cash bonus payment of $\$ 1.2$ million for the year despite IAG reporting the lowest net profit after tax, ROA and ROE since 2012. Overall, these results are consistent with the contention that powerful CEOs use the conditions of cash bonus contracts to camouflage high compensation levels.

\section{Conclusion}

This study examines whether powerful CEOs influence the conditions of their cash bonus contracts. First, based on a sample of 1,085 firm years of ASX 500 firms, CEO power is found 
to be positively associated with the ex ante bonus ratio and the use of non-financial performance targets into cash bonus contracts. The effects are greater for firms that pay cashonly compensation. Second, we find that the proportion of cash bonus weighted against nonfinancial performance targets is not related to subsequent firm performance; however, nonfinancial targets that are quantitative or related to CSR are positively related to subsequent firm performance. These results support the view that measurable targets, which are less easily manipulated, as well as targets related to CSR, translate to increased subsequent firm performance (e.g., Cook et al. 2019; Edmans, 2011; Ittner \& Larcker, 1998; Lev et al., 2010). Furthermore, firms that do not provide any information regarding the types of non-financial performance targets used in cash bonus contracts experience lower subsequent firm performance, which suggests that these firms are attempting to camouflage high CEO compensation levels. While our results are robust to controls for endogeneity including a twostage least squares estimation and propensity score-matched subsamples, we cannot completely rule out the endogeneity problem, which is a limitation of this study.

This study contributes to the literature that examines the relative importance of managerial power and efficient contracting theory in determining CEO compensation. Specifically, our findings illustrate that, although CEOs influence the conditions of their cash bonus arrangement, non-financial performance targets do not necessarily impact firm performance negatively. However, qualitative and undefined non-financial performance targets appear to be less effective at incentivising CEOs. This supports shareholders' concerns regarding bonus payouts associated with unjustified non-financial performance targets. Future research may examine whether our results hold on equity-based compensation contracts which have started to use non-financial targets (Ryan, 2017). 


\section{Reference List}

Abernethy, M. A., Kuang, Y. F., \& Qin, B. (2015). The influence of CEO power on compensation contract design. Accounting Review, 90(4), 1265-1306.

Alissa, W. (2015). Boards' response to shareholders' dissatisfaction: The case of shareholders' say on pay in the UK. European Accounting Review, 24(4), 727-752.

Armstrong, C. S., Ittner, C. D., \& Larcker, D. F. (2010). Corporate Governance, Compensation Consultants, and CEO pay levels. Working Paper, University of Pennsylvania and Stanford University.

Arnold, M. C., \& Grasser, R. (2018). What is a fair amount of executive compensation? Outrage potential of two key stakeholder groups. Journal of Business Finance \& Accounting, 45(5-6), 651-685.

ASX Corporate Governance Council (2014). Corporate governance principles and $\begin{array}{llll}\text { recommendations, } & \text { viewed } & \text { August }\end{array}$ <http://www.asx.com.au/regulation/corporate-governance-council.htm>.

Balsam, S., Gifford, R. H. \& Puthenpurackal, J. (2017). Related party transaction, corporate governance and CEO Compensation. Journal of Business Finance \& Accounting, 44(5), 854-894.

Bebchuk, L.A., \& Fried, J.M. (2003). Executive compensation as an agency problem. Journal of Economic Perspectives, 17(3), 71-92.

Bebchuk, L.A., \& Fried, J.M. (2005). Pay without performance: overview of the issues. Journal of Applied Corporate Finance, 17(4), 8-23.

Becker, C.L., Defond, M.L., Jiambalvo, J., \& Subramanyam, K.R. (1998). The effect of audit quality on earnings management. Contemporary Accounting Research, 15(1), 1-24.

Bennett, B., Bettis, J.C., Gopalan, R., \& Milbourn, T. (2017). Compensation goals and firm performance. Journal of Financial Economics, 124(2), 307-330.Bugeja, M., Matolcsy, Z., \& Spiropoulos, H. (2017). The CEO pay slice: Managerial power or efficient contracting? Some indirect evidence. Journal of Contemporary Accounting and Economics, 13, (1), 69-87. 
Bushman, R. M., Indjejikian, R. J., \& Smith, A. (1996). CEO compensation: The role of individual performance evaluation. Journal of Accounting and Economics, 21(2), 161193.

Cai, Y., Jo, H., \& Pan, C. (2012). Doing well while doing bad? CSR in controversial industry sectors. Journal of Business Ethics, 108(4), 467-480.

Cho, M., Ibrahim, S. \& Yan, Y. (2019). The use of nonfinancial performance measures in CEO bonus compensation. Corporate Governance: An International Review, 27(4), 301-316.

Choi, A., Choi, J., \& Sohn, B.C. (2018). The joint effect of audit quality and legal regimes on the use of real earnings management: International evidence. Contemporary Accounting Research, 35(4), 2225-2257.

Clarkson, P. M., Van Bueren, A. L. \& Walker, J. K. (2006). Chief executive officer remuneration disclosure quality: corporate responses to an evolving disclosure environment. Accounting and Finance, 46(5), 771-796.

Clarkson, P. M., Walker, J., \& Nicholls, S. (2011). Disclosure, shareholder oversight and the pay-performance link. Journal of Contemporary Accounting and Economics, 7(2), 4764.

Cohen, J., Krishnamoorthy, G., \& Wright, A.M., (2002). Corporate governance and the audit process. Contemporary accounting research, 19(4), 573-594.

Coles, J. L., Daniel, N. D., \& Naveen, L. (2014). Co-opted boards. Review of Financial Studies, 27(6), 1751-1796.

Collins, D., Marquardt, B. B., \& Niu, X., (2019). Equity-based incentives and shareholder sayon pay. Journal of Business Finance \& Accounting, 46(5-6), 739-761.

Conyon, M. J., Fernandes, N., Ferreira, M. A., Matos, P., \& Murphy, K. J. (2011). The executive compensation controversy: A transatlantic analysis. viewed 6 July 2017, ILR School, Institute for Compensation Studies <http:digitalcommons.ilr.cornell.edu/ics/5>

Conyon, M. J., \& Peck, S. I. (1998). Board control, remuneration committees, and top management. Academy of Management Journal, 41(2), 146-157.

Cook, K. A., Romi, A. M., Sánchez, D. \& Sánchez, J. M. (2019). The influence of corporate social responsibility on investment efficiency and innovation. Journal of Business 
Finance \& Accounting, 46(3-4), 494-537.Core, J. E., Holthausen, R. W., \& Larcker, D. F. (1999). Corporate governance, chief executive officer compensation, and firm performance. Journal of Financial Economics, 51(3), 371-406.

Correa, R., \& Lel, U. (2016). Say on pay laws, executive compensation, pay slice, and firm valuation around the world. Journal of Financial Economics, 122(3), 500-520.

DeAngelo, L.E., (1981). Auditor size and audit quality. Journal of accounting and economics, 3(3), 183-199.

Dhaliwal, D., Li, O. Z., Tsang, A., \& Yang, G. Y. (2011). Voluntary nonfinancial disclosure and the cost of equity capital: The initiation of corporate social responsibility reporting. The Accounting Review, 86(1), 59-100.

Edmans, A. (2011). Does the stock market fully value intangibles? Employee satisfaction and equity prices. Journal of Financial Economics, 621-640.

van Essen, M., Otten, J., \& Carberry, E. J. (2015). Assessing managerial power theory. Journal of Management, 41(1), 164-202.

Finkelstein, S. (1992). Power in top management teams: Dimensions, measurement, and validation. The Academy of Management Journal, 35(3), 505-538.

Francis, J.R., Khurana, I.K. and Pereira, R. (2003). The role of accounting and auditing in corporate governance and the development of financial markets around the world. AsiaPacific Journal of Accounting \& Economics, 10(1), 1-30.

Francis, J.R. and Yu, M.D. (2009). Big 4 office size and audit quality. The Accounting Review, 84(5), 1521-1552.

Frydman, C., \& Jenter, D. (2010). CEO compensation, The Annual Review of Financial Economics, 2(1), 75-102.

Gerhart, B. A., \& Milkovich, G. T. (1990). Organizational differences in managerial compensation and financial performance. Academy of Management Journal, 33(4), 663691.

Gibbs, M., Merchant, K. A., Van der Stede, W. A., \& Vargus, M. E. (2004). Determinants and effects of subjectivity in incentives. The Accounting Review, 79(2), 409-436.

Grosse, M., Kean, S., \& Scott, T. (2017). Shareholder say on pay and CEO compensation: Three strikes and the board is out. Accounting \& Finance, 57(3), 701-725. 
Grosse, M., Ma, N., \& Scott, T. (2019). Evidence on compensation consultant fees and CEO pay. Australian Journal of Management. Forthcoming, Available at: https://doi.org/10.1177/0312896219837999

Gruca, T. S., \& Rego, L. L. (2005). Customer satisfaction, cash flow, and shareholder value. Journal of marketing, 69(3), 115-130.

Guay, W. R. (1999). The sensitivity of CEO wealth to equity risk: An analysis of the magnitude and determinants. Journal of Financial Economics, 53(1), 43-71.

Guay, W. R., Kepler, J. D., \& Tsui, D. (2019). The role of executive cash bonuses in providing individual and team incentives. Journal of Financial Economics, Forthcoming. Available at: https://doi.org/10.1016/j.jfineco.2019.02.007.

Hong, B., Li, Z., \& Minor, D. (2016). Corporate governance and executive compensation for corporate social responsibility. Journal of Business Ethics, 136(1), 199-213.

Holmstrom, B. (1979). Moral hazard and observability. The Bell Journal of Economics, 10(1), 74-91.

Höppe, F., \& Moers, F. (2011). The choice of different types of subjectivity in CEO annual bonus contracts. The Accounting Review, 86(6), 2023-2046.

Iliev, P., \& Vitanova, S. (2019). The Effect of the Say-on-Pay Vote in the United States. Management Science, Forthcoming, Available at: https://doi.org/10.1287/mnsc.2018.3062

Ittner, C. D., Larcker, D. F., \& Rajan, M. V. (1997). The choice of performance measures in annual bonus contracts. Accounting Review, 72(2), 231-255.

Ittner, C. D., \& Larcker, D. F. (1998). Are nonfinancial measures leading indicators of financial performance? An analysis of customer satisfaction. Journal of Accounting Research, 36, $1-35$.

Ittner, C. D., \& Larcker, D. F. (2001). Assessing empirical research in managerial accounting: a value-based management perspective. Journal of accounting and economics, 32(1), 349-410.

Ittner, C. D., \& Larcker, D. F. (2009). Extending the boundaries: Nonfinancial performance measures. Handbooks of management accounting research, 3, 1235-1251.

Jensen, M. C. (1993). The modern industrial revolution, exit, and the failure of internal control systems. Journal of Finance, 48(3), 831-880. 
Jensen, M. C., \& Meckling, W. H. (1976). Theory of the firm: Managerial behaviour, agency costs and ownership structure. Journal of Financial Economics, 3(4), 305-360.

Joo, J. H., \& Chamberlain, S. L. (2017). The effects of governance on classification shifting and compensation shielding. Contemporary Accounting Research, 34(4), 1779-1811.

Kane, E. J. (2002). Using deferred compensation to strengthen the ethics of financial regulation. Journal of Banking \& Finance, 26, 1919-1933.

Knight, E. (2016). Shareholders reject AGL boss' mega-million pay cheque. Sydney Morning Herald, viewed 29 September 2017, <http://www.smh.com.au/business/energy/shareholders-reject-agl-boss-megamillionpay-cheque-20160928-grqi4w.html>

Krishnan, G.V. (2003). Audit quality and the pricing of discretionary accruals. Auditing: A journal of practice \& theory, 22(1), 109-126.

Lev, B., Petrovits, C., \& Radhakrishnan, S. (2010). Is doing good good for you? How corporate charitable contributions enhance revenue growth. Strategic Management Journal, 31(2), 182-200.

Lisic, L. L., Neal, T. L., Zhang, I. X., \& Zhang, Y. (2016). CEO power, internal control quality, and audit committee effectiveness in substance versus in form. Contemporary Accounting Research, 33(3), 1199-1237.

Mahoney, L. S., \& Thorne, L. (2005). Corporate social responsibility and long-term compensation: Evidence from Canada. Journal of Business Ethics, 57(3), 241-253.

Mahoney, L. S., \& Thorne, L. (2006). An examination of the structure of executive compensation and corporate social responsibility: A Canadian investigation. Journal of Business Ethics, 69(2), 149-162.

Maley, K. (2018). The battle royale over banks bonuses, Sydney Morning Herald, viewed 15 April 2018, https://www.afr.com/business/banking-and-finance/the-battle-royale-overbank-bonuses-20181217-h197c1

Mao, C. X., \& Weathers, J. (2019). Employee treatment and firm innovation. Journal of Business Finance \& Accounting, 46 (7-8), 977-1002 
Matolcsy, Z., Tyler, J., \& Wells, P. (2011). The impact of quasi-regulatory reforms on boards and their committees during the period 2001-2007. Australian Accounting Review, 21(4), $352-64$.

Matolcsy, Z., \& Wright, A. (2007). Australian CEO compensation: The descriptive evidence. Australian Accounting Review, 17(4)3, 47-59.

Matolcsy, Z., \& Wright, A. (2011). CEO compensation structure and firm performance. Accounting and Finance, 51(3), 745-63.

McGuire, J., Schneeweis, T., \& Sundgren, A. (1988). Corporate social responsibility and firm financial performance. Academy of Management Journal, 31(4), 854-872.

McKendall, M., Sanchez, C., \& Sicilian, P. (1999). Corporate governance and corporate illegality: The effects of board structure on environmental violations. International Journal of Organizational Analysis, 7(3), 201-223.

Morse, A., Nanda, V., \& Seru, A. (2011). Are incentive contracts rigged by powerful CEOs? Journal of Finance, 66(5), 1779-821.

Murphy, K. (2000). Performance standards in incentive contracts. Journal of Accounting \& Economics, 30(3), 245-278.

Murphy, K. (2013). Executive compensation: Where we are, and how we got there. Handbook of The Economics of Finance, 2(Part A), 211-356.

Murphy, K., \& Sandino, T. (2019). Compensation Consultants and the Level, Composition and Complexity of CEO Pay, The Accounting Review, Forthcoming, Available at: https://doi.org/10.2308/accr-52439

O’Connor, N. G., Deng, F. J., \& Fei, P. (2015). Observability and subjective performance measurement. Abacus, 51(2), 208-237.

O'Connell, V., \& O'Sullivan, D. (2011). The impact of customer satisfaction on CEO bonuses. Journal of the Academy of Marketing Science, 39(6), 828-845.

O'Connell, V., \& O'Sullivan, D. (2014). The influence of lead indicator strength on the use of nonfinancial measures in performance management: Evidence from CEO compensation schemes. Strategic Management Journal, 35(6), 826-844.

Rajan, M.V., \& Reichelstein, S. (2009). Objective versus subjective indicators of managerial performance. The Accounting Review, vol 84(1), 209-237. 
Robertson, A. (2016). Executive pay: "Soft" bonus targets under the spotlight this corporate AGM season. ABC News, viewed 16 July 2017, <http://www.abc.net.au/news/2016-1011/soft-bonuses-major-talking-point-as-agm-season-underway/7913764> .

Rose, S. (2017). ACSI takes aim at CEO bonuses. Investment Magazine, viewed 26 September 2017, <https://investmentmagazine.com.au/2017/08/acsi-takes-aim-at-ceo-bonuses/> .

Rosenbaum, P. R. (2001). Observational studies: Overview. International Encyclopedia of the Social \& Behavioral Sciences, 10808-10815.

Rosenbaum, P. R. \& Rubin, D. B. (1983). The central role of the propensity score in observational studies for causal effects. Biometrika, 70(1), 41-55.

Ryan, P. (2017). Commonwealth Bank bonuses to be measured against "trust" and "reputation". $\quad A B C \quad$ News, viewed $30 \quad$ September 2017, <http://www.abc.net.au/news/2017-09-29/cba-bonuses-to-be-measured-against-trustand-reputation/9000908>.

Shan, Y., \& Walter, T. (2016). Towards a set of design principles for executive compensation contracts. Abacus, 52(4), 619-684.

Shaw, K. W., \& Zhang, M. H. (2010). Is CEO cash compensation punished for poor firm performance? Accounting Review, 85(3), 1065-1093.

Sloan, R.G. (2001). Financial accounting and corporate governance: a discussion. Journal of accounting and economics, 32(1-3), 335-347.

Smith, C. W., \& Watts, R. L. (1982). Incentive and tax effects of executive compensation plans. Australian Journal of Management, 7(2), 139-157.

Song, W. L., \& Wan, K. M. (2019). Does CEO compensation reflect managerial ability or managerial power? Evidence from the compensation of powerful CEOs. Journal of Corporate Finance, 56, 1-14.

Tuli, K. P., \& Bharadwaj, S. G. (2009). Customer satisfaction and stock returns risk. Journal of Marketing, 73(6), 184-197.

Yeates, C. (2017). Low bar: Almost every top CEO gets their bonus, study shows. The Sydney $\begin{array}{llll}\text { Morning } \quad \text { Herald, } & \text { viewed } & \text { September }\end{array}$ $<$ http://www.smh.com.au/business/banking-and-finance/chief-executive-performancebonuses-consistently-high-acsi-20170823-gy2c6d.html>. 
Zalewski, D. (2003). Corporate objectives: Maximizing social versus private equity. Journal of Economic Issues, 37(2), 503-509. 


\section{Tables}

TABLE 1 Definition of variables

\begin{tabular}{l} 
Variable \\
\hline Panel A: Dependent variables \\
Bonus Ratio
\end{tabular}

\section{Definition}

Bonus Ratio

Non_Fin. Ratio

$R_{O A} A_{t+1}($ Ind-adj $)$
The maximum ex ante cash bonus available to the CEO as a proportion of base salary as stated in the firm's remuneration report;

The proportion of cash bonus weighted towards nonfinancial targets of performance as stated in the firm's remuneration report;

Industry-adjusted earnings before interest and tax divided by total assets;

Panel B: Key independent variable CEO Power Index

A measure of CEO power composed of the sum of eight individual components divided by the maximum components available to the CEO*. The sum is established based on the following indicator variables coded 1 if: (i) $C E O$ Tenure $\geq 75^{\text {th }}$ percentile; (ii) $C E O$ Shareholding $\geq 75^{\text {th }}$ percentile; (iii) Board Size $\geq 75^{\text {th }}$ percentile; (iv) \%Independent $\leq 75^{\text {th }}$ percentile; (v) CEO_Com $\geq 75^{\text {th }}$ percentile; (vi) On_Nom $=1$; (vii) On_Rem $=1$; (viii) Coopted_Rem $=1$;

*Some firms do not have a remuneration and (nor) nomination committee and CEOs of these firms are only able to achieve a maximum of 7(6) components.

Qualitative

Undefined

Quantitative

An indicator variable coded 1 if the non-financial target is non-quantifiable (these include: Improve staff engagement, Talent management, Demonstrate leadership skills, People and culture, Succession planning, Strategic planning, Response to competition/competitive environment, Sustainability, Environmental and Stakeholder engagement), 0 otherwise;

An indicator variable coded 1 if the non-financial target is not specified, 0 otherwise;

An indicator variable coded 1 if the non-financial target is quantifiable (these include: OH\&S targets, Decrease injury rates, Operation performance/operational excellence, Growth and new market development, Compliance with governance standards, Customer satisfaction and Quality of recommendations), 0 otherwise;

CSR

An indicator variable coded 1 if non-financial targets capture CSR activities (these include: $O H \& S$ targets, Decrease injury rates, Compliance with governance 
standards, Customer satisfaction, Improve staff engagement, Talent management, People and culture, Sustainability, Environmental and Stakeholder engagement), 0 otherwise;

Panel C: CEO Power Index CEO Tenure

\section{CEO Shareholding}

\section{Board Size}

\%Independent

CEO_Com

On_Nom

On_Rem

Coopted_Rem

\section{Panel D: Control variables}

$R O A_{t-1}$

lnSize t-1 $_{1-1}$

$\operatorname{stdROA}_{t-1}$

$\operatorname{lnCash}_{t-1}$

Return $_{t-1}$

Leverage $_{t-1}$

$M / B_{t-1}$

$\Delta$ Salary

Consultant
The number of years in which the $\mathrm{CEO}$ has been employed as the CEO;

The number of shares held by the CEO divided by total outstanding shares;

The number of directors on the board of directors excluding the CEO;

The number of independent directors on the board divided by the total number of directors on the board; The number of committees of which the CEO is a member divided by the total number of committees established by the firm;

An indicator variable coded 1 if the CEO is a member of the nomination committee, 0 otherwise;

An indicator variable coded 1 if the CEO is a member of the remuneration committee, 0 otherwise;

An indicator variable coded 1 if more than 50 percent of the remuneration committee has been co-opted, 0 otherwise;

Earnings before interest and tax divided by total assets; The natural log of total assets;

The standard deviation of return on asset (ROA) measured earnings before interest and tax divided by total assets;

The natural log of cash flow from operations scaled by total assets;

Annual stock return;

Total long-term debt divided by total shareholders' equity;

The market price of outstanding shares divided by total shareholders' equity;

The annual percentage change in the individual CEO's base salary;

An indicator variable coded 1 if the firm employed an external remuneration consultant during the financial year, 0 otherwise. 
TABLE 2 Sample construction

Panel A Sample selection

ASX500 firms from 2004 to 2016 from Connect4 database

Less: Firms that do not disclose information on bonus compensation in their $(1,436)$

annual reports

Less: Firms that explicitly state that they do not provide bonus

compensation

Less: CEOs paid from another firm

Less: Firms with co-CEOs

Less: Firms where CEO replaced during year

Less: Firms with missing data to run model (1)

Sample to test $H 1$

Less: Firms without data to calculate non-financial targets

Sample to test $H 2$ and $H 3 \mathrm{a}-\mathrm{d}$

Panel B Sample distribution by year

\begin{tabular}{rrr}
\hline Year & $\mathrm{n}$ & Percentage \\
\hline 2004 & 2 & 1.843 \\
2005 & 37 & 3.410 \\
2006 & 42 & 3.871 \\
2007 & 50 & 4.608 \\
2008 & 60 & 5.530 \\
2009 & 63 & 5.806 \\
2010 & 82 & 7.558 \\
2011 & 91 & 8.839 \\
2012 & 108 & 9.954 \\
2013 & 117 & 10.783 \\
2014 & 140 & 12.903 \\
2015 & 137 & 12.627 \\
2016 & 156 & 14.378 \\
\hline Total & 1,085 & 100.000 \\
\hline
\end{tabular}

Panel C Sample distribution by industry (2 digit GICS)

\begin{tabular}{lrr}
\hline Industry & $\mathrm{n}$ & Percentage \\
\hline Energy & 73 & 6.728 \\
Materials & 216 & 19.908 \\
Industrials & 146 & 13.456 \\
Consumer Discretionary & 189 & 17.419 \\
Consumer Staples & 88 & 8.111 \\
Health Care & 77 & 7.097 \\
Financials & 118 & 10.876 \\
Information Technology & 69 & 6.359 \\
Telecommunication Services & 2 & 0.737 \\
Utilities & 19 & 1.751 \\
Real Estate & 88 & 8.111 \\
\hline Total & 1,085 & 100.000 \\
\hline
\end{tabular}


TABLE 3 Descriptive statistics

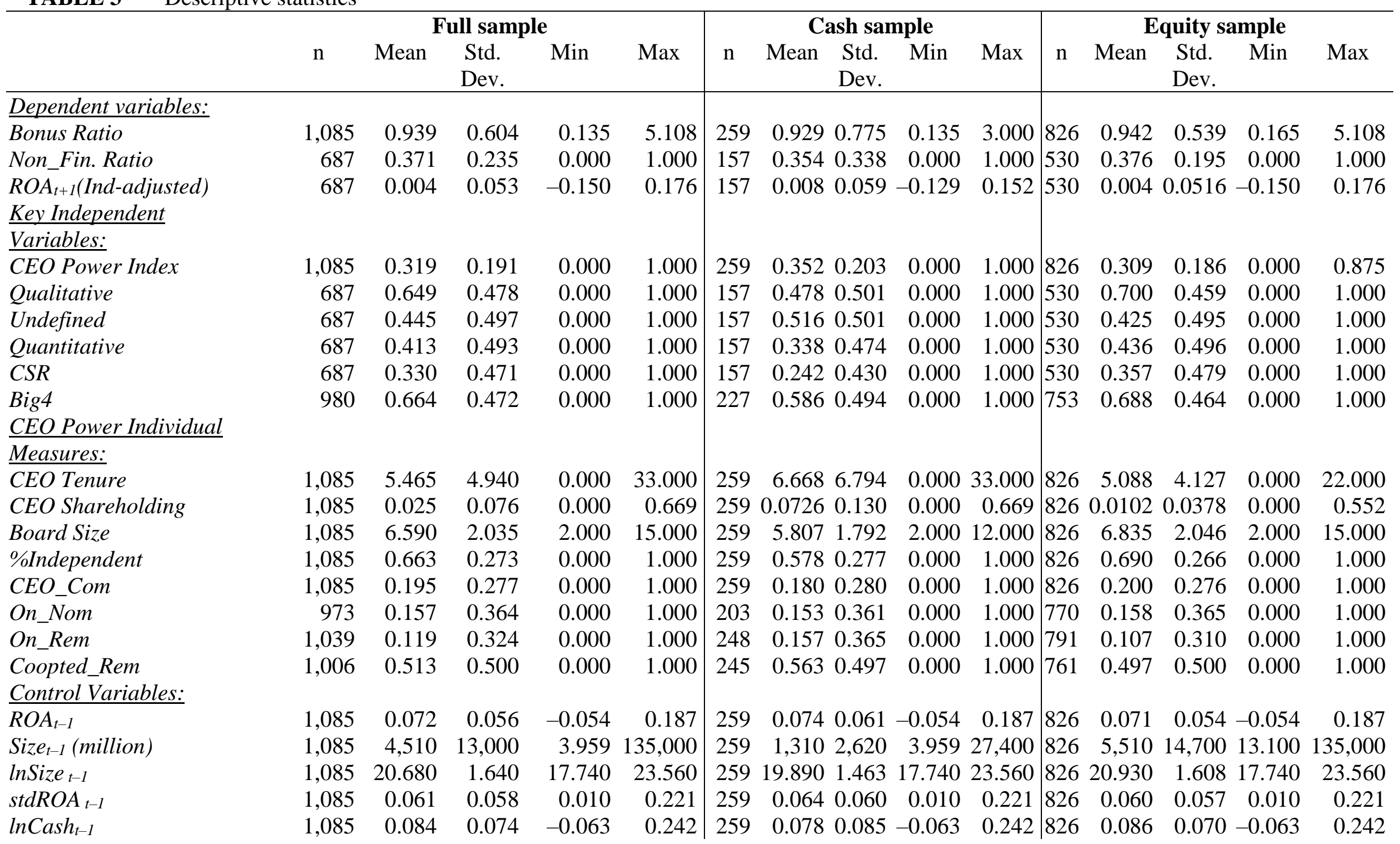




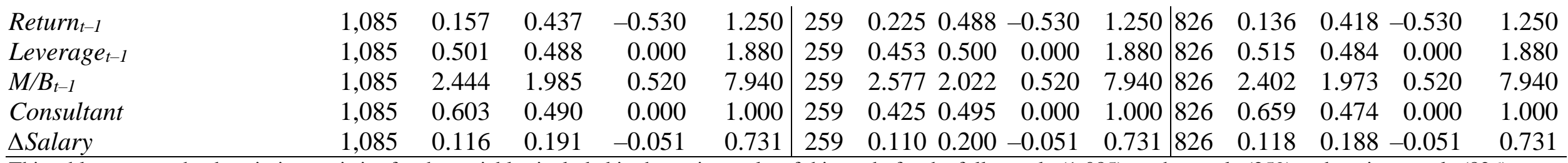

This table presents the descriptive statistics for the variables included in the main results of this study for the full sample (1,085), cash sample (259) and equity sample (826).

Bonus Ratio is the maximum ex ante cash bonus available to the CEO as a proportion of base salary as stated in the firm's remuneration report; Non_Fin. Ratio is the proportion of cash bonus weighted towards non-financial targets of performance as stated in the firm's remuneration report; $R O A_{t+1}$ (Ind-adjusted) is the industry-adjusted earnings before interest and tax divided by total assets; CEO Power Index is a measure of CEO power composed of the sum of eight individual components divided by the maximum components available to the CEO. The sum is established based on the following indicator variables coded 1 if: (i) $C E O$ Tenure $\geq 75^{\text {th }}$ percentile; (ii) $C E O$ Shareholding $\geq 75^{\text {th }}$ percentile; (iii) Board Size $\geq 75^{\text {th }}$ percentile; (iv) \%Independent $\leq 75^{\text {th }}$ percentile; (v) $C E O \_C o m \geq 75^{\text {th }}$ percentile; (vi) On_Nom $=1$; (vii) On_Rem $=1$; (viii) Coopted_Rem $=1$;

Qualitative is an indicator variable coded 1 if the non-financial target is non-quantifiable, 0 otherwise; Undefined is an indicator variable coded 1 if the non-financial target is not specified, 0 otherwise; Quantitative is an indicator variable coded 1 if the non-financial target is quantifiable, 0 otherwise; CSR is an indicator variable coded 1 if non-financial targets capture CSR activities, 0 otherwise; CEO Tenure is the number of years in which the CEO has been employed as CEO; CEO Shareholding is the number of shares held by the CEO divided by total outstanding shares; Board Size is the number of directors on the board of directors excluding the CEO; \%Independent is the number of independent directors on the board divided by the total number of directors on the board; $C E O$ COm is the number of committees of which the CEO is a member divided by the total number of committees established by the firm; On_Nom is an indicator variable coded 1 if the CEO is a member of the nomination committee, 0 otherwise; On_Rem: is an indicator variable coded 1 if the CEO is a member of the remuneration committee, 0 otherwise; Coopted_Rem: is an indicator variable coded 1 if more than 50 percent of the remuneration committee has been co-opted, 0 otherwise; $R O A_{t-l}$ is earnings before interest and tax divided by total assets; $\operatorname{lnSiz} e_{t-l}$ is the natural log of total assets; $s t d R O A_{t-l}$ is the standard deviation of return on asset (ROA) measured earnings before interest and tax divided by total assets; Cash $_{t-l}$ is cash flow from operations; $\ln$ Cash $h_{t-1}$ is the natural log of cash flow from operations scaled by total assets; Return $t_{t-l}$ is annual stock return; Leverage $_{t-l}$ is total long-term debt divided by total shareholders' equity; $M / B_{t-l}$ is the market price of outstanding shares divided by total shareholders' equity; Consultant is an indicator variable coded 1 if the firm employed an external remuneration consultant during the financial year, 0 otherwise; $\Delta$ Salary is the annual percentage change in the individual CEO's base salary. All continuous variables are winsorized at the top and bottom 5 percent. 
TABLE 4 Correlation matrix

\begin{tabular}{|c|c|c|c|c|c|c|c|c|c|c|c|c|c|c|c|c|c|c|c|c|c|c|c|c|}
\hline & 1 & & 2 & & 3 & & 4 & & 5 & & 6 & & 7 & & 8 & & 9 & & 10 & & 11 & & 12 & \\
\hline 1. Bonus Ratio & 1 & & & & & & & & & & & & & & & & & & & & & & & \\
\hline 2. Non_Fin.Ratio & 0.0579 & * & 1 & & & & & & & & & & & & & & & & & & & & & \\
\hline 3. $R O A_{t=I}$ (Ind-adjusted) & 0.0654 & & -0.0347 & & 1 & & & & & & & & & & & & & & & & & & & \\
\hline 4. CEO Power Index & 0.0458 & * & 0.0623 & * & 0.0428 & & 1 & & & & & & & & & & & & & & & & & \\
\hline 5. Qualitative & 0.0826 & $* * *$ & 0.3167 & $* * *$ & -0.0129 & & -0.0824 & $* * *$ & 1 & & & & & & & & & & & & & & & \\
\hline 6. Undefined & -0.0658 & **** & -0.2202 & $* * *$ & -0.0496 & & 0.082 & $* * *$ & -0.6787 & $* * *$ & 1 & & & & & & & & & & & & & \\
\hline 7. Quantitative & 0.0664 & $* * *$ & 0.1535 & $* * *$ & 0.051 & & -0.0869 & $* * *$ & 0.5039 & $* * *$ & -0.8265 & *** & 1 & & & & & & & & & & & \\
\hline 8. CSR & 0.0654 & $* * * *$ & 0.2263 & $* * *$ & 0.1161 & $* *$ & -0.0596 & $* * *$ & 0.4933 & $* * *$ & -0.6693 & $* * *$ & 0.6927 & $* * *$ & 1 & & & & & & & & & \\
\hline 9. CEO Tenure & -0.0142 & & 0.0166 & & 0.1435 & $* *$ & 0.481 & $* * *$ & 0.0251 & & -0.013 & & -0.0115 & & -0.0208 & & 1 & & & & & & & \\
\hline 10. CEO Shareholding & -0.0231 & & -0.1064 & $* * * *$ & 0.0719 & * & 0.3113 & $* * *$ & -0.077 & $* * *$ & 0.0771 & $* * *$ & -0.0887 & $* * *$ & -0.097 & $* * *$ & 0.2871 & $* * *$ & 1 & & & & & \\
\hline 11. CEO_Com & 0.0174 & & 0.0155 & & 0.0528 & & 0.4469 & $* * *$ & -0.0048 & & -0.0139 & & 0.0062 & & 0.0556 & $* * *$ & 0.0644 & **** & -0.0335 & & 1 & & & \\
\hline 12. Board size & 0.1039 & $* * *$ & 0.0747 & & -0.1491 & $* * *$ & 0.0767 & $* * *$ & 0.1455 & $* * *$ & -0.1105 & **** & 0.0957 & $* * *$ & 0.0998 & $* * *$ & -0.1036 & $* * *$ & -0.2892 & $* * *$ & 0.132 & $* * *$ & 1 & \\
\hline 13. \%Indepdent & 0.0458 & * & -0.0262 & & 0.0066 & & -0.2751 & $* * *$ & 0.0987 & $* * *$ & -0.1062 & $* * *$ & 0.0935 & $* * *$ & 0.1097 & $* * * *$ & 0.0222 & & -0.08 & $* * *$ & 0.0376 & * & .0 .0308 & ** \\
\hline 14. On_Nom & 0.0648 & * & 0.0328 & & 0.0088 & & 0.5379 & $* * *$ & -0.0527 & $* *$ & 0.0222 & & -0.0132 & & 0.0216 & & 0.0574 & ** & -0.0251 & & 0.389 & $* * *$ & -0.0493 & \\
\hline 15. On_Rem & 0.0674 & $* * *$ & 0.0768 & $* *$ & 0.0332 & & 0.5825 & $* * *$ & -0.0461 & $* *$ & 0.0189 & & -0.0494 & $* *$ & 0.0186 & & 0.1332 & $* * *$ & 0.1123 & $* * *$ & 0.4732 & $* * *$ & -0.132 & $* * *$ \\
\hline 16.Coopted_Rem & -0.0218 & & 0.0206 & & 0.0973 & $* *$ & 0.5515 & $* * *$ & 0.0103 & & 0.0138 & & 0.0038 & & -0.0396 & $* *$ & 0.4908 & $* * *$ & 0.1772 & $* * *$ & 0.0378 & * & -0.0649 & $* * *$ \\
\hline 17. $R O A_{t-1}$ & 0.0008 & & -0.2051 & $* * *$ & 0.5336 & $* * *$ & 0.0292 & & -0.0215 & & 0.0384 & & 0.006 & & 0.0205 & & 0.0932 & $* * *$ & 0.0784 & $* * *$ & 0.019 & & -0.1395 & $* * *$ \\
\hline 18. $\ln$ Size $_{t-1}$ & 0.3522 & $* * *$ & 0.207 & $* * *$ & -0.1262 & $* * *$ & 0.0117 & & 0.2302 & $* * *$ & -0.1482 & $* * *$ & 0.1362 & $* * *$ & 0.142 & $* * *$ & -0.0442 & & -0.2585 & $* * *$ & 0.1661 & $* * *$ & -0.6065 & $* * *$ \\
\hline 19. $s t d R O A_{t-1}$ & -0.1838 & $* * *$ & 0.1831 & $* * *$ & 0.1176 & $* * *$ & -0.0067 & & -0.0525 & * & 0.0342 & & -0.0171 & & 0.0504 & * & -0.0875 & $* * *$ & 0.1015 & $* * *$ & -0.0591 & * & -0.171 & \\
\hline 20. $\ln \operatorname{Cash}_{t-1}$ & -0.0081 & & -0.0845 & $* *$ & 0.4732 & $* * *$ & 0.0176 & & 0.0151 & & 0.0037 & & 0.0391 & & 0.0689 & $* *$ & 0.1028 & $* * *$ & 0.0294 & & 0.0265 & & -0.1687 & $* * *$ \\
\hline 21. Return Rt-1 & -0.016 & & -0.039 & & 0.2445 & $* * *$ & 0.0442 & & -0.0209 & & 0.0607 & $* *$ & -0.0539 & * & -0.0427 & & 0.0273 & & 0.1502 & $* * *$ & -0.0251 & & -0.1207 & $* * *$ \\
\hline 22. Leverage $t-1$ & 0.1771 & $* * *$ & 0.0852 & ** & -0.0568 & & 0.0686 & ** & 0.1018 & * & -0.0588 & * & 0.0398 & & 0.0321 & & -0.0537 & * & -0.0734 & $* *$ & 0.0523 & * & -0.222 & $* * *$ \\
\hline 23. $M / B_{t-1}$ & -0.0669 & $* *$ & -0.0475 & & 0.4036 & $* * *$ & 0.0054 & & 0.0095 & & 0.1037 & $* * *$ & -0.0773 & $* *$ & -0.0703 & $* *$ & 0.0292 & & 0.0907 & $* * *$ & -0.0182 & & -0.1267 & $* * *$ \\
\hline 24. $\Delta$ Salary & -0.0644 & $* *$ & -0.0653 & & 0.0045 & & -0.0838 & $* *$ & -0.0433 & & 0.0608 & $* *$ & -0.0675 & $* *$ & -0.0611 & $* *$ & -0.1746 & $* * *$ & -0.0085 & & 0.0128 & & -0.0326 & \\
\hline 25. Consultant & -0.0029 & & -0.0002 & & 0.0117 & & -0.0396 & * & 0.0437 & $* *$ & -0.042 & * & 0.0652 & $* * *$ & 0.0691 & $* * *$ & -0.0156 & & -0.1454 & $* * *$ & 0.0732 & $* * *$ & 0.2143 & $* * *$ \\
\hline
\end{tabular}




\begin{tabular}{|c|c|c|c|c|c|c|c|c|c|c|c|c|c|c|c|}
\hline & 13. & & 14. & 15. & 16. & 17. & 18. & 19. & 20. & 21. & 22. & 23. & 24. & & 25. \\
\hline 13. \%Indepdent & 1.0000 & & & & & & & & & & & & & & \\
\hline 14. On_Nom & -0.0169 & & 1.0000 & & & & & & & & & & & & \\
\hline 15. On_Rem & -0.0682 & **** & $0.6245 * *$ & 1.0000 & & & & & & & & & & & \\
\hline 16. Coopted_Rem & -0.0237 & & 0.0303 & 0.0278 & 1.0000 & & & & & & & & & & \\
\hline 17. $R O A_{t-1}$ & 0.0221 & & 0.0458 & 0.0391 & 0.0588 & 1.0000 & & & & & & & & & \\
\hline 18. $\operatorname{lnSize} e_{t-1}$ & 0.1510 & $* * *$ & -0.0279 & $-0.0666 *$ & $-0.0867 * *$ & $-0.1780 * *$ & 1.0000 & & & & & & & & \\
\hline 19. stdROA $A_{t-1}$ & -0.0813 & $* * *$ & 0.0045 & $-0.0702 *$ & $0.0748^{*}$ & $-0.0804 * *$ & $-0.3828 * *$ & 1.0000 & & & & & & & \\
\hline 20. $\ln \operatorname{Cash}_{t-1}$ & 0.0656 & $* *$ & 0.0267 & 0.0479 & $0.0926 * *$ & $0.6757 * *$ & $-0.1674 * *$ & 0.0387 & 1.0000 & & & & & & \\
\hline 21. Return ${ }_{t-1}$ & -0.0060 & & 0.0153 & 0.0579 & 0.0895 ** & $0.1475 * *$ & $-0.1664 * *$ & $0.0840 * *$ & $0.1339: * *$ & 1.0000 & & & & & \\
\hline 22. Leverage $t-1$ & -0.0174 & & -0.0077 & 0.0205 & -0.0495 & $-0.0980 * *$ & $0.3467 * *$ & $-0.2699 * *$ & $-0.1810: * *$ & $-0.0604 *$ & 1.0000 & & & & \\
\hline 23. $M / B_{t-1}$ & 0.0163 & & -0.0802 & -0.0343 & $0.0933^{* * *}$ & $0.3998 * *$ & $-0.2531 * *$ & $0.1556 * *$ & $0.2986: * *$ & $0.3217 * *$ & $0.0873 * *$ & 1.0000 & & & \\
\hline 24. $\Delta$ Salary & -0.0339 & & 0.0516 & 0.0369 & $-0.1347 * *$ & -0.0005 & -0.0559 & 0.0333 & -0.0212 & $0.0978 * *$ & -0.0295 & 0.0555 & & 1.0000 & \\
\hline 25. Consultant & 0.1522 & $* * *$ & -0.0179 & $-0.0472 *$ & 0.0000 & 0.0008 & $0.1583 * *$ & $-0.0944 * *$ & 0.0467 & -0.0454 & $0.1887 * *$ & $0.0853 \mathrm{k} *$ & & 0.0033 & 1 \\
\hline
\end{tabular}

This table presents the correlations for all variables. Bonus Ratio is the maximum ex ante cash bonus available to the CEO as a proportion of base salary as stated in the firm's remuneration report; Non Fin. Ratio is the proportion of cash bonus weighted towards non-financial targets of performance as stated in the firm's remuneration report; $R O A_{t+l}($ Ind-adjusted) is the industry-adjusted earnings before interest and tax divided by total assets; CEO Power Index is a measure of CEO power composed of the sum of eight individual components divided by the maximum components available to the CEO. The sum is established based on the following indicator variables coded 1 if: (i) CEO Tenure $\geq 75^{\text {th }}$ percentile; (ii) CEO Shareholding $\geq 75^{\text {th }}$ percentile; (iii) Board Size $\geq 75^{\text {th }}$ percentile; (iv) $\%$ Independent $\leq 75^{\text {t }}$ percentile; (v) CEO_Com $\geq 75^{\text {th }}$ percentile; (vi) On_Nom $=1$; (vii) On_Rem $=1$; (viii) Coopted_Rem=1; Qualitative is an indicator variable coded 1 if the non-financial target is non-quantifiable, 0 otherwise; Undefined is an indicator variable coded 1 if the non-financial target is not specified, 0 otherwise; Quantitative is an indicator variable coded 1 if the non-financial target is quantifiable, 0 otherwise; CSR is an indicator variable coded 1 if non-financial targets capture CSR activities, 0 otherwise; $C E O$ Tenure is the number of years in which the CEO has been employed as CEO; CEO Shareholding is the number of shares held by the CEO divided by total outstanding shares; Board Size is the number of directors on the board of directors excluding the CEO; \%Independent is the number of independent directors on the board divided by the total number of directors on the board; CEO_Com is the number of committees of which the CEO is a member divided by the total number of committees established by the firm; On_Nom is an indicator variable coded 1 if the CEO is a member of the nomination committee, 0 otherwise; On_Rem: is an indicator variable coded 1 if the CEO is a member of the remuneration committee, 0 otherwise; Coopted_Rem: is an indicator variable coded 1 if more than 50 percent of the remuneration committee has been co-opted, 0 otherwise; $R O A_{t-l}$ is earnings before interest and tax divided by total assets; $\operatorname{lnSize} e_{t-l}$ is the natural log of total assets; $s t d R O A_{t-l}$ is the standard deviation of return on asset (ROA) measured earnings before interest and tax divided by total assets; Cash $h_{t-1}$ is cas flow from operations; $\ln$ Cash $_{t-l}$ is the natural log of cash flow from operations scaled by total assets; Return $_{t-l}$ is annual stock return; Leverage $_{t-l}$ is total long-term debt divided by total shareholders' equity; $M / B_{t-1}$ is the market price of outstanding shares divided by total shareholders' equity; Consultant is an indicator variable coded 1 if the firm employed an external remuneration consultant during the financial year, 0 otherwise; $\triangle$ Salary is the annual percentage change in the individual CEO's base salary. All continuous variables are winsorized at the top and bottom 5 percent. 
TABLE 5 Univariate analysis of all variables split at the median of CEO Power Index

\begin{tabular}{|c|c|c|c|c|c|}
\hline & \multicolumn{2}{|c|}{$\begin{array}{r}\text { Low CEO } \\
\text { Power }\end{array}$} & \multicolumn{2}{|c|}{ High CEO } & \multirow[b]{2}{*}{$\begin{array}{l}\text { Statistical } \\
\text { difference }\end{array}$} \\
\hline & $\mathrm{n}$ & Mean & Obs. & Mean & \\
\hline \multicolumn{6}{|l|}{ Dependent variables: } \\
\hline Bonus Ratio & 566 & 0.892 & 519 & 0.990 & $-2.686 * * *$ \\
\hline Non_Fin. Ratio & 368 & 0.352 & 315 & 0.391 & $-2.221 * *$ \\
\hline$R O A_{t+1}($ Ind-adjusted $)$ & 368 & 0.001 & 315 & 0.009 & $-2.040 * *$ \\
\hline \multicolumn{6}{|c|}{ Key Independent Variables: } \\
\hline CEO Power Index & 566 & 0.171 & 519 & 0.481 & $-45.839 * * *$ \\
\hline Qualitative & 368 & 0.625 & 315 & 0.673 & -1.309 \\
\hline Undefined & 368 & 0.446 & 315 & 0.444 & 0.032 \\
\hline Quantitative & 368 & 0.424 & 315 & 0.406 & 0.464 \\
\hline CSR & 368 & 0.313 & 315 & 0.352 & -1.104 \\
\hline \multicolumn{6}{|c|}{ CEO Power Individual Measures: } \\
\hline$\overline{C E O ~ T e n u r e ~}$ & 566 & 3.541 & 519 & 7.565 & $-14.668 * * *$ \\
\hline CEO Shareholding & 566 & 0.011 & 519 & 0.041 & $-6.540 * * *$ \\
\hline Board Size & 566 & 6.276 & 519 & 6.933 & $-5.379 * * *$ \\
\hline \%Independent & 566 & 0.729 & 519 & 0.590 & $8.667 * * *$ \\
\hline CEO_Com & 566 & 0.093 & 519 & 0.306 & $-13.720 * * *$ \\
\hline On_Nom & 515 & 0.029 & 458 & 0.301 & $-12.535 * * *$ \\
\hline On_Rem & 550 & 0.020 & 489 & 0.231 & $-11.066 * * *$ \\
\hline Coopted_Rem & 550 & 0.262 & 489 & 0.789 & $-19.641 * * *$ \\
\hline \multicolumn{6}{|l|}{ Control Variables: } \\
\hline$R O A_{t-1}$ & 566 & 0.070 & 519 & 0.073 & -0.821 \\
\hline $\operatorname{lnSize}_{t-1}$ & 566 & 20.633 & 519 & 20.730 & -0.975 \\
\hline $\operatorname{stdROA}_{t-1}$ & 566 & 0.060 & 519 & 0.061 & -0.445 \\
\hline $\operatorname{lnCash} \operatorname{Cal}_{t-1}$ & 566 & 0.085 & 519 & 0.084 & 0.154 \\
\hline Return $_{t-1}$ & 566 & 0.144 & 519 & 0.172 & -1.058 \\
\hline Leverage $_{t-1}$ & 566 & 0.461 & 519 & 0.544 & $-2.802 * * *$ \\
\hline$M / B_{t-1}$ & 566 & 2.423 & 519 & 2.467 & -0.367 \\
\hline Consultant & 566 & 0.601 & 519 & 0.605 & -0.145 \\
\hline$\Delta$ Salary & 566 & 0.133 & 519 & 0.098 & $3.060 * * *$ \\
\hline
\end{tabular}

This table presents the results of differences in means and medians for all variables in the regression model for firms that have a CEO with high CEO power versus low CEO power. A test of statistical difference for firms with CEOs with high CEO power versus those with CEOs with low CEO power is also shown. A $t-$ test is used for continuous variables and a $\chi 2$-test for indicator variables. The * $* *$ and *** represent statistical significance at the ten, five and one percent levels, respectively. Bonus Ratio is the maximum ex ante cash bonus available to the CEO as a proportion of base salary as stated in the firm's remuneration report; Non_Fin. Ratio is the proportion of cash bonus weighted towards non-financial targets of performance as stated in the firm's remuneration report; $R O A_{t+1}$ (Ind-adjusted) is the industry-adjusted earnings before interest and tax divided by total assets; CEO Power Index is a measure of CEO power composed of the sum of eight individual components divided by the maximum components available to the CEO. The sum is established based on the following indicator variables coded 1 if: (i) CEO Tenure $\geq 75^{\text {th }}$ percentile; (ii) $C E O$ Shareholding $\geq 75^{\text {th }}$ percentile; (iii) Board Size $\geq 75^{\text {th }}$ percentile; (iv) \%Independent $\leq$ $75^{\text {th }}$ percentile; (v) CEO_Com $\geq 75^{\text {th }}$ percentile; (vi) On_Nom $=1$; (vii) On_Rem $=1$; (viii) Coopted_Rem $=1$; Qualitative is an indicator variable coded 1 if the non-financial target is non-quantifiable, 0 otherwise; Undefined is an indicator variable coded 1 if the non-financial target is not specified, 0 otherwise; Quantitative is an indicator variable coded 1 if the non-financial target is quantifiable, 0 otherwise; CSR is 
an indicator variable coded 1 if non-financial targets capture CSR activities, 0 otherwise; CEO Tenure is the number of years in which the $\mathrm{CEO}$ has been employed as CEO; CEO Shareholding is the number of shares held by the CEO divided by total outstanding shares; Board Size is the number of directors on the board of directors excluding the CEO; \%Independent is the number of independent directors on the board divided by the total number of directors on the board; CEO_Com is the number of committees of which the CEO is a member divided by the total number of committees established by the firm; On_Nom is an indicator variable coded 1 if the CEO is a member of the nomination committee, 0 otherwise; On_Rem is an indicator variable coded 1 if the CEO is a member of the remuneration committee, 0 otherwise; Coopted_Rem is an indicator variable coded 1 if more than 50 percent of the remuneration committee has been co-opted, 0 otherwise; $R O A_{t-l}$ is earnings before interest and tax divided by total assets; $\operatorname{lnSiz} e_{t-1}$ is the natural log of total assets; $s t d R O A_{t-l}$ is the standard deviation of return on asset (ROA) measured earnings before interest and tax divided by total assets; Cash $_{t-1}$ is cash flow from operations; $\ln$ Cash $_{t-1}$ is the natural log of cash flow from operations scaled by total assets; Return $t_{t-1}$ is the annual stock return; Leverage $_{t-1}$ is total long-term debt divided by total shareholders' equity; $M / B_{t-}$ is the market price of outstanding shares divided by total shareholders' equity; Consultant is an indicator variable coded 1 if the firm employed an external remuneration consultant during the financial year, 0 otherwise; $\Delta$ Salary is the annual percentage change in the individual CEO's base salary. All continuous variables are winsorized at the top and bottom 5 percent. 
TABLE 6 The influence of CEO power on the Bonus Ratio

\begin{tabular}{|c|c|c|c|c|}
\hline Variables & $\begin{array}{l}\text { Predicted } \\
\text { sign }\end{array}$ & $\begin{array}{c}\text { Full sample } \\
\text { (1) }\end{array}$ & $\begin{array}{c}\text { Cash sample } \\
\text { (2) }\end{array}$ & $\begin{array}{c}\text { Equity sample } \\
\text { (3) }\end{array}$ \\
\hline Constant & & $\begin{array}{c}-1.801 * * * \\
(-6.223)\end{array}$ & $\begin{array}{l}-1.620^{*} \\
(-1.935)\end{array}$ & $\begin{array}{l}-2.250 * * * \\
(-10.708)\end{array}$ \\
\hline CEO Power Index & + & $\begin{array}{c}0.288 * * * \\
(5.391)\end{array}$ & $\begin{array}{c}0.543 * * * \\
(3.635)\end{array}$ & $\begin{array}{c}0.167 * * * \\
(3.168)\end{array}$ \\
\hline$R O A_{t-1}$ & + & $\begin{array}{c}0.118 \\
(0.194)\end{array}$ & $\begin{array}{c}0.937 \\
(0.664)\end{array}$ & $\begin{array}{l}-0.850 \\
(-1.530)\end{array}$ \\
\hline $\operatorname{lnSize}_{t-1}$ & + & $\begin{array}{l}0.120 * * * \\
(7.809)\end{array}$ & $\begin{array}{c}0.109 * * \\
(2.919)\end{array}$ & $\begin{array}{l}0.141 * * * \\
(13.812)\end{array}$ \\
\hline $\operatorname{stdROA}_{t-1}$ & $+1-$ & $\begin{array}{l}-0.208 \\
(-1.025)\end{array}$ & $\begin{array}{l}1.358 \\
(1.750)\end{array}$ & $\begin{array}{l}-0.689 * * \\
(-2.870)\end{array}$ \\
\hline $\operatorname{lnCash}_{t-1}$ & + & $\begin{array}{c}0.515 \\
(1.248)\end{array}$ & $\begin{array}{l}-0.737 \\
(-1.008)\end{array}$ & $\begin{array}{c}1.290 * * * \\
(3.794)\end{array}$ \\
\hline Return $_{t-1}$ & + & $\begin{array}{c}0.053 \\
(1.155)\end{array}$ & $\begin{array}{c}0.063 \\
(0.679)\end{array}$ & $\begin{array}{c}0.027 \\
(0.492)\end{array}$ \\
\hline Leverage $_{t-1}$ & $+/-$ & $\begin{array}{c}0.049 \\
(1.079)\end{array}$ & $\begin{array}{c}0.098 \\
(0.712)\end{array}$ & $\begin{array}{l}-0.014 \\
(-0.434)\end{array}$ \\
\hline$M / B_{t-1}$ & + & $\begin{array}{c}0.004 \\
(0.366)\end{array}$ & $\begin{array}{l}-0.011 \\
(-0.451)\end{array}$ & $\begin{array}{l}0.020 * \\
(1.911)\end{array}$ \\
\hline Consultant & + & $\begin{array}{l}-0.017 \\
(-0.905)\end{array}$ & $\begin{array}{c}-0.264 * * * \\
(-3.415)\end{array}$ & $\begin{array}{c}0.078 * * \\
(2.918)\end{array}$ \\
\hline$\Delta$ Salary & - & $\begin{array}{c}-0.103 \\
(-1.452)\end{array}$ & $\begin{array}{c}-0.103 \\
(-0.596)\end{array}$ & $\begin{array}{c}-0.094 \\
(-1.124)\end{array}$ \\
\hline Year controls & & Yes & Yes & Yes \\
\hline Industry controls & & Yes & Yes & Yes \\
\hline $\begin{array}{l}\mathrm{n} \\
\text { Adjusted R-squared }\end{array}$ & & $\begin{array}{l}1,085 \\
0.189\end{array}$ & $\begin{array}{c}259 \\
0.177\end{array}$ & $\begin{array}{c}826 \\
0.260\end{array}$ \\
\hline
\end{tabular}

This table presents the results for Model (1) with Bonus Ratio as the dependent variable and tests the influence of CEO power on CEOs' cash bonus ratio. The regression is specified as:

Bonus Ratio $=\alpha+\beta_{1}$ CEO Power Index $+\beta_{2}$ Coopted_50 $+\beta_{3}$ CEO Power Index $\times$ Coopted_50

$+\beta_{4-12} \sum$ Firm Controls $+\beta_{13-25}$ Year $+\beta_{26-35}$ Industry $+\epsilon_{i}$

Bonus Ratio is the maximum ex ante cash bonus available to the CEO as a proportion of base salary as stated in the firm's remuneration report; CEO Power Index is a measure of CEO power composed of the sum of eight individual components divided by the maximum components available to the CEO. The sum is established based on the following indicator variables coded 1 if: (i) CEO Tenure $\geq 75^{\text {th }}$ percentile; (ii) CEO Shareholding $\geq 75^{\text {th }}$ percentile; (iii) Board Size $\geq 75^{\text {th }}$ percentile; (iv) \%Independent $\leq 75^{\text {th }}$ percentile; (v) $C E O \_C o m \geq 75^{\text {th }}$ percentile; (vi) On_Nom $=1$; (vii) On_Rem =1; (viii) Coopted_Rem $=1 ; R O A_{t-1}$ is earnings before interest and tax divided by total assets; InSize $t_{t-l}$ is the natural log of total assets; $s t d R O A_{t-l}$ is the standard deviation of return on asset (ROA) measured earnings before interest and tax divided by total assets; Cash $_{t-l}$ is cash flow from operations; $\operatorname{lnCash}_{t-l}$ : is the natural $\log$ of cash flow from operations scaled by total assets; Return $_{t-l}$ is annual stock return; Leverage $_{t-1}$ : is total long-term debt divided by total shareholders' equity; $M / B_{t-1}$ is the market price of outstanding shares divided by total shareholders' equity; Consultant is an indicator variable coded 1 if the firm employed an external remuneration consultant during the financial year, 0 otherwise; $\Delta$ Salary is the annual percentage change in the individual CEO's base salary. All continuous variables are winsorized at the top and bottom 5 percent. Standard errors are clustered by year. 
TABLE 7 The influence of CEO power on the Non_Fin. Ratio

\begin{tabular}{|c|c|c|c|c|}
\hline & $\begin{array}{l}\text { Predicted } \\
\text { sign }\end{array}$ & $\begin{array}{c}\text { Full sample } \\
(1)\end{array}$ & $\begin{array}{c}\text { Cash sample } \\
(2) \\
\end{array}$ & $\begin{array}{c}\text { Equity sample } \\
\text { (3) }\end{array}$ \\
\hline Constant & & $\begin{array}{c}-0.605 * * * \\
(-3.441)\end{array}$ & $\begin{array}{l}-0.717 \\
(-1.009)\end{array}$ & $\begin{array}{l}-0.547 * * \\
(-2.388)\end{array}$ \\
\hline CEO Power Index & + & $\begin{array}{c}0.091 * * \\
(2.550)\end{array}$ & $\begin{array}{l}0.292 * \\
(2.093)\end{array}$ & $\begin{array}{c}0.090 * * \\
(2.379)\end{array}$ \\
\hline$R O A_{t-1}$ & - & $\begin{array}{l}-0.329 * \\
(-1.920)\end{array}$ & $\begin{array}{l}-0.896^{*} \\
(-2.013)\end{array}$ & $\begin{array}{c}-0.389 * * \\
(-2.629)\end{array}$ \\
\hline $\operatorname{lnSize}_{t-1}$ & + & $\begin{array}{c}0.042 * * * \\
(5.941)\end{array}$ & $\begin{array}{c}0.045 \\
(1.628)\end{array}$ & $\begin{array}{c}0.040 * * * \\
(4.509)\end{array}$ \\
\hline $\operatorname{stdROA}_{t-1}$ & $+/-$ & $\begin{array}{c}1.445^{* * *} \\
(9.139)\end{array}$ & $\begin{array}{c}1.971 * * * \\
(5.612)\end{array}$ & $\begin{array}{c}1.145 * * * \\
(4.847)\end{array}$ \\
\hline $\operatorname{lnCash} \operatorname{Cal}_{t-1}$ & + & $\begin{array}{l}0.273^{*} \\
(1.823)\end{array}$ & $\begin{array}{c}0.751 \\
(1.688)\end{array}$ & $\begin{array}{c}0.216 \\
(1.433)\end{array}$ \\
\hline Return $_{t-1}$ & + & $\begin{array}{c}0.011 \\
(0.387)\end{array}$ & $\begin{array}{c}0.061 \\
(1.322)\end{array}$ & $\begin{array}{l}-0.016 \\
(-0.439)\end{array}$ \\
\hline Leverage $_{t-1}$ & $+/-$ & $\begin{array}{l}-0.027 * \\
(-2.123)\end{array}$ & $\begin{array}{c}0.071 \\
(1.670)\end{array}$ & $\begin{array}{l}-0.040^{*} \\
(-1.924)\end{array}$ \\
\hline$M / B_{t-1}$ & - & $\begin{array}{c}0.002 \\
(0.302)\end{array}$ & $\begin{array}{l}-0.023 \\
(-1.552)\end{array}$ & $\begin{array}{c}0.012 \\
(1.500)\end{array}$ \\
\hline Consultant & + & $\begin{array}{l}-0.028^{* *} \\
(-2.949)\end{array}$ & $\begin{array}{l}-0.008 \\
(-0.136)\end{array}$ & $\begin{array}{l}-0.024 \\
(-1.780)\end{array}$ \\
\hline$\Delta$ Salary & - & $\begin{array}{c}-0.112 * * \\
(-2.831)\end{array}$ & $\begin{array}{l}-0.247 * \\
(-2.058)\end{array}$ & $\begin{array}{l}-0.059 \\
(-1.130)\end{array}$ \\
\hline $\begin{array}{l}\text { Year controls } \\
\text { Industry controls }\end{array}$ & & $\begin{array}{l}\text { Yes } \\
\text { Yes }\end{array}$ & $\begin{array}{l}\text { Yes } \\
\text { Yes }\end{array}$ & $\begin{array}{l}\text { Yes } \\
\text { Yes }\end{array}$ \\
\hline $\begin{array}{l}\mathrm{n} \\
\text { Adjusted R-squared }\end{array}$ & & $\begin{array}{c}687 \\
0.148\end{array}$ & $\begin{array}{c}157 \\
0.298\end{array}$ & $\begin{array}{c}530 \\
0.135\end{array}$ \\
\hline
\end{tabular}

This table presents the results for Model (1) with Non_Fin. Ratio as the dependent variable and tests the influence of CEO power on the proportion of cash bonus weighted towards non-financial performance targets. The regression is specified as:

$$
\begin{aligned}
& \text { Non_Fin. Ratio }=\alpha+\beta_{1} \text { CEO Power Index }+\beta_{2} \text { Coopted_50 }+\beta_{3} \text { CEO Power Index } \times \text { Coopted }_{50} \text { (1) } \\
& +\beta_{4-12} \sum \text { Firm Controls }+\beta_{13-25} \text { Year }+\beta_{26-35} \text { Industry }+\epsilon_{i}
\end{aligned}
$$

Non_Fin. Ratio is the proportion of cash bonus weighted towards non-financial targets of performance as stated in the firm's remuneration report; $R O A_{t+1}($ Ind-adjusted) is industry-adjusted earnings before interest and tax divided by total assets; CEO Power Index is a measure of CEO power composed of the sum of eight individual components divided by the maximum components available to the CEO. The sum is established based on the following indicator variables coded 1 if: (i) CEO Tenure $\geq 75^{\text {th }}$ percentile; (ii) CEO Shareholding $\geq 75^{\text {th }}$ percentile; (iii) Board Size $\geq 75^{\text {th }}$ percentile; (iv) \%Independent $\leq 75^{\text {th }}$ percentile; (v) CEO_Com $\geq 75^{\text {th }}$ percentile; (vi) On_Nom =1; (vii) On_Rem $=1$; (viii) Coopted_Rem $=1 ; R O A_{t-1}$ is earnings before interest and tax divided by total assets; $\operatorname{lnSize}_{t-1}$ is the natural log of total assets; $s t d R O A_{t-l}$ is the standard deviation of return on asset (ROA) measured earnings before interest and tax divided by total assets; Cash $_{t-1}$ is cash flow from operations; $\ln$ Cash $_{t-1}$ : is the natural log of cash flow from operations scaled by total assets; $\operatorname{Return}_{t-1}$ is annual stock return; Leverage $t_{t-l}$ is total long-term debt divided by total shareholders' equity; $M / B_{t-l}$ is the market price of outstanding shares divided by total shareholders' equity; Consultant is an indicator variable coded 1 if the firm employed an external remuneration consultant during the financial year, 0 otherwise; $\Delta$ Salary is the annual percentage change in the individual CEO's base salary. All continuous variables are winsorized at the top and bottom 5 percent. Standard errors are clustered by year. 
TABLE 8 The impact of including non-financial performance targets in bonus contracts on subsequent firm performance

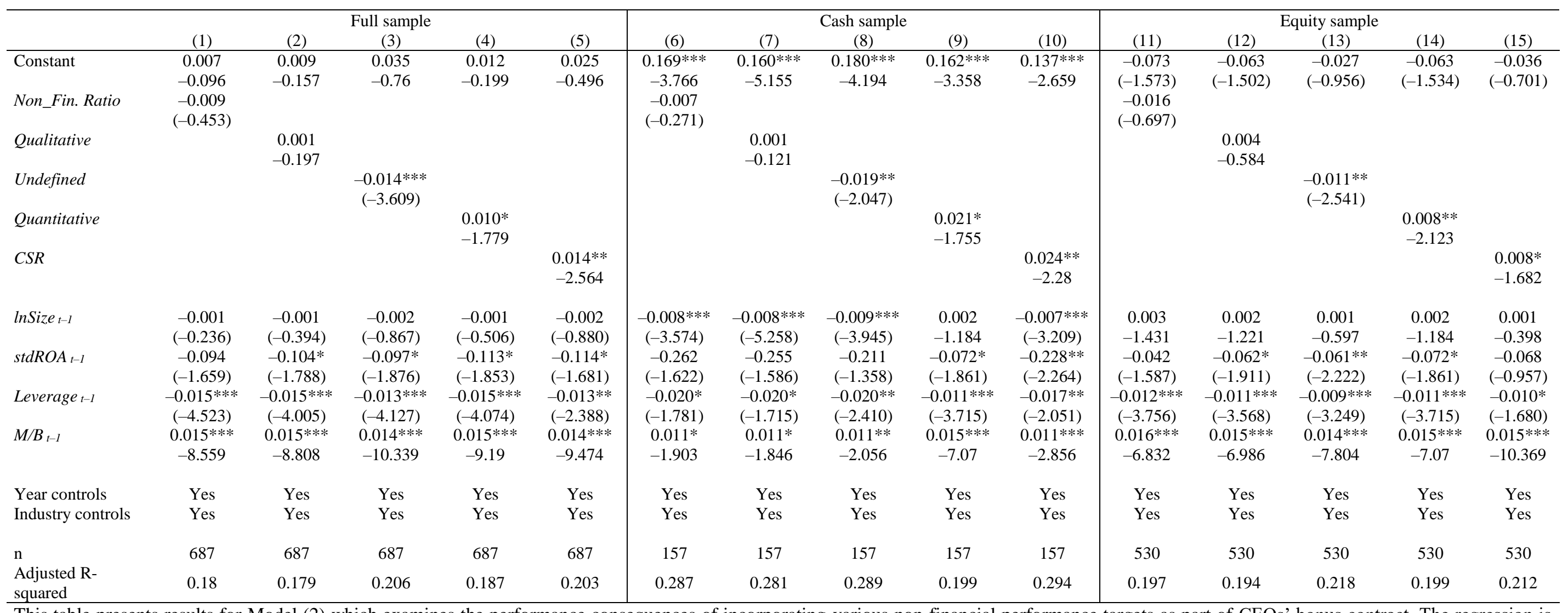

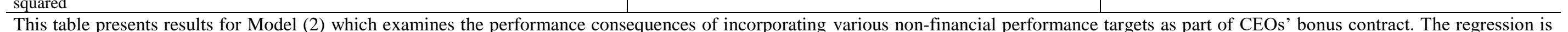
specified as:

$R O A_{t+1}($ Ind.adj $)=\alpha+\beta_{1}$ Non_Fin.Ratio $+\beta_{2-5}$ SFirm Controls $+\beta_{5-18}$ Year $+\beta_{19-28}$ Industry $+\epsilon_{i}$

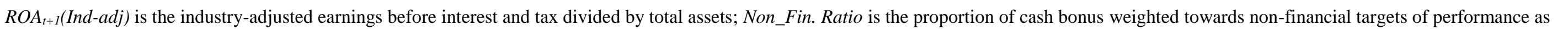

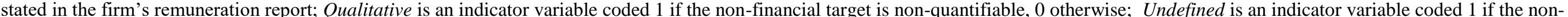

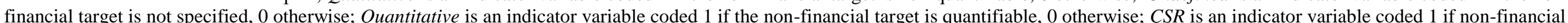

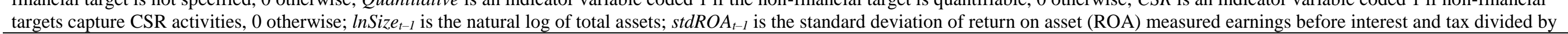


total assets; Leverage $t-l_{t}$ is total long-term debt divided by total shareholders' equity; $M / B_{t-l}$ is the market price of outstanding shares divided by total shareholders' equity. All continuous variables are winsorized at the top and bottom 5 percent. The *,** and *** represent statistical significance at the ten, five, one percent levels, respectively. Standard errors are clustered by year and industry. 
TABLE 9 Heckman SLS estimation of CEO Power

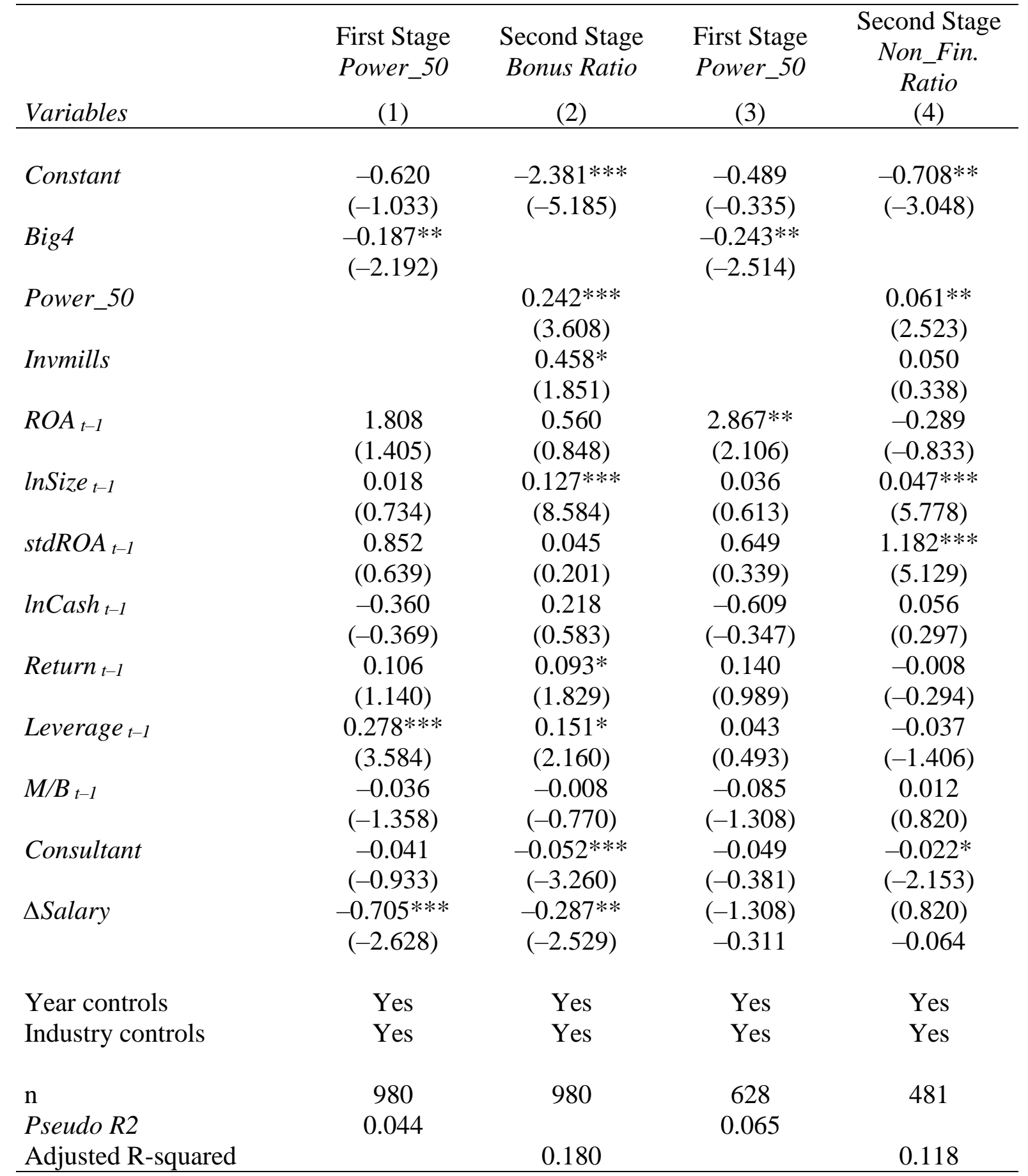

This table presents results for a Heckman 2SLS estimation which addresses the notion of self-selection. Columns (1) and (3) present the results for the first stage which estimates a probit regression for the determinants of CEO power where Power_50 is the dependent variable. Column (2) presents the results for the second stage which incorporates the Invmills estimated in the first stage and where Bonus Ratio is the dependent variable. Column (4) presents the results for the second stage which incorporates the Invmills estimates in the first stage and where Non-Fin Ratio is the dependent variable. N in columns (1), (2), (3) and (4) is different to prior tables as Big4 data is unavailable for some firms.

Power_50 is an indicator variable coded 1 if CEO Power is greater than the median, 0 otherwise; Big4 is an indicator variable coded 1 if the firm is audited by one of the Big4 audit firms, 0 otherwise; Bonus Ratio is the maximum ex ante cash bonus available to the CEO as a proportion of base salary as stated in the firm's remuneration report; Non-Fin Ratio is the proportion of cash bonus weighted towards non-financial targets of performance as stated in the firm's remuneration report; $R O A_{t-l}$ is earnings before interest and tax divided by total assets; $\operatorname{lnSize} e_{t-1}$ is the natural log of total assets; $s t d R O A_{t-l}$ is the standard deviation of return on asset 
(ROA) measured earnings before interest and tax divided by total assets. $\ln \operatorname{Cash}_{t-l}$ is the natural $\log$ of cash flow from operations scaled by total assets; Return $_{t-1}$ is annual stock return; Leverage $e_{t-1}$ is total long-term debt divided by total shareholders' equity; $M / B_{t-1}$ is the market price of outstanding shares divided by total shareholders' equity; Consultant is an indicator variable coded 1 if the firm employed an external remuneration consultant during the financial year, 0 otherwise; $\Delta$ Salary is the annual percentage change in the individual CEO's base salary. All continuous variables are winsorized at the top and bottom 5 percent. The *, $* *$ and $* * *$ represent statistical significance at the ten, five, one percent levels, respectively. Standard errors are clustered by year. 
${ }^{1}$ Figure 2.1 in Murphy (2013) illustrates that, while equity-based compensation comprises 21-32 percent of average total realised compensation of CEOs included in the S\&P 500 in 2011, realised cash bonuses range between 20-24 percent. Similarly, Figure 2.3 illustrates that total cash compensation increased from USD 1.1 million in 1970 to USD 4.1 million in 2011.

2 This is partly driven by Section 162(m) of the Internal Revenue Code 1986 which implements a USD 1 million tax deduction limit on CEO compensation arrangements. Nonetheless, equity-based incentives, such as stock option grants, qualify for the performance-based compensation exemption to Section 162(m). This exemption provides economic incentives that make equity-based compensation attractive to employers, as cash bonuses rarely qualify. The same exemption for equity-based compensation does not apply in Australia.

${ }^{3}$ While prior U.S. studies have shown that CEO duality increases CEO power, CEO duality is less common in Australia. We find that only one firm in our final sample (Reece Australia Limited) has a CEO who is also the chairman. This observation is not included in our final sample and as such, CEO duality is not included in our CEO Power Index.

4 Matolcsy and Wright (2011) document that within the Australian setting, from 1999 to 2005, cash-only based incentives as well as equity-based incentives can be efficient based on the economic characteristics of firms. Furthermore, either incentive arrangement has negative performance consequences only if the firm has chosen an incentive arrangement that is inconsistent with its economic characteristics.

${ }^{5}$ We acknowledge that discretion still remains concerning the application of accounting standards; hence, we cannot rule out that some manipulation may occur in relation to financial targets. However, given industry comparisons, year-to-year trends, and external auditors, financial targets are less likely to be manipulated to the same degree as non-financial targets.

${ }^{6} \mathrm{H} 2$ is also tested using a Tobit model due to the number of 0 values in the sample. Untabulated results are consistent with those reported in Table 7.

${ }^{7}$ For example, Abernethy et al. (2015), Finkelstein (1992), Jensen (1993), Lisic et al. (2016), and van Essen et al. (2015).

${ }^{8}$ Finkelstein (1992) identifies structural power, ownership power, expert power and prestige power as the four key aspects that enable individuals to manage and influence corporate decisions. Prestige power is not considered as part of the power index as data is unavailable in the Australian setting.

${ }^{9}$ The average size of the remuneration committee in the sample is 3.635 . The smallest committee size is 1 director, whereas the largest committee size is 9 directors.

${ }^{10}$ Shaw and Zhang (2010) provide a simple timeline (Figure 1, p. 1067) of events associated with incentive contracts. First, at the end of year $t-1$ (beginning of year $t$ ), CEOs and remuneration committees agree upon $e x$ ante contracts to be used in evaluating and rewarding CEO performance in year $t$. At the end of year $t$, year $t$ 's actual performance is observed and compared to ex ante conditions in order to finalise CEO compensation for year $t$.

${ }^{11}$ This study does not control for firm fixed effects due to the limited sample size. The sample contains 220 individual firms. The average number of times each firm is present in the sample is 4.93 .

12 Not all firms report the specific breakdown of the performance weights applied in the CEO's bonus contract. Therefore, the subsample to test $H 2$ as well as the performance consequences of non-financial targets $(H 3 a-d)$, is reduced by 398 observations.

${ }^{13}$ Sensitivity tests are performed where data is winsorized at the top and bottom one percent. Untabulated results are consistent as reported in the main tables.

14 Abernethy et al. (2015) provide evidence that CEOs' influence their equity-based compensation in the U.S. setting. 
15 The result is in contrast to Ittner et al. (1997) who find no association between CEO power and the use of nonfinancial performance targets used in cash bonus contracts. A comparison of the measures of CEO power applied in this study versus those applied by Ittner et al. (1997) may explain the differing results, as may the use of different sample years and settings. Similar reasons may explain contrasting evidence to a recent study by Cho, Ibrahim and Yan (2019).

16 See Armstrong, Ittner, and Larcker (2010), Rosenbaum (2001), and Rosenbaum and Rubin (1983) for discussion and application of the propensity score matching procedure.

${ }^{17}$ We thank an anonymous reviewer for raising this issue.

${ }^{18}$ Therefore, powerful CEOs ultimately realise more total cash compensation because they are receiving a greater proportion of a greater bonus ratio. 